\title{
Hydrometeorological factors determining the development of water table cave patterns in high alpine zones. The Ordesa and Monte Perdido National Park, NE Spain
}

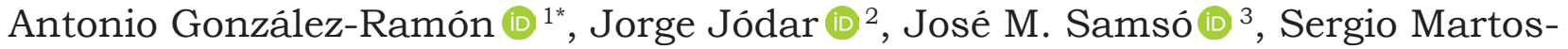

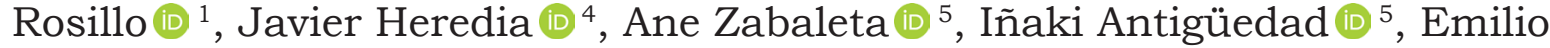 \\ Custodio (1) ${ }^{6,7}$, and Luis J. Lambán (10 ${ }^{2}$ \\ ${ }^{1}$ Geological and Mining Institute of Spain, Urb. Alcázar del Genil, 4. Edf. Zulema bajo, 18006, Granada, Spain \\ ${ }^{2}$ Geological and Mining Institute of Spain, C/ Manuel Lasala, $44-9^{\circ}$ B, 50006 Zaragoza, Spain \\ ${ }^{3}$ Consulting Geologist, C/ Mayor 30, $1^{\circ} .22700$ Jaca, Huésca, Spain \\ ${ }^{4}$ Geological and Mining Institute of Spain, C/ Rios Rosas, 23, 28003, Madrid, Spain \\ ${ }^{5}$ Hydro-Environmental Processes Group, Science and Technology Faculty, University of the Basque Country UPV/EHU, Sarriena z/g, 48940 Leioa, Spain \\ ${ }^{6}$ Groundwater Hydrology Group, Department of Civil and Environmental Engineering, Technical University of Catalonia, C/ Jordi Girona, \\ 1 - 3 UPC Campus Nord, Edificio D2, 08034 Barcelona, Spain \\ ${ }^{7}$ Spanish Royal Academy of Sciences, Madrid, Spain
}

Abstract: $\quad$ This study is focussed on the geomorphological characterization and the processes driving the evolution of the highest karst system in Western Europe, which is located in the Ordesa and Monte Perdido National Park (PNOMP), in the central-southern Pyrenees. The karst system does not seem to have a well-developed epikarst. The studied area shows a karst network of polygenic branchwork type in the vadose zone. Additionally, the explored karst conduits in the epiphreatic zone show a water table cave pattern that is different to the looping one, which is the expected cave pattern development for a karst located in a mountain zone where a high irregular recharge is expected. We have designed a conceptual recharge model through a multidisciplinary approach, which has included the making of a new detailed geological and hydrogeological map of the study area, morphometric analysis of cavities, tests with fluorescent dye tracers and hydrometeorological monitoring of the karst system associated with the Garcés Spring. This spring, together with the Font Blanca Spring, constitutes the main water discharge point of the hydrogeological system. The conceptual recharge model explains how the observed unexpected cave pattern has developed in this karst.

Keywords: $\quad$ Ordesa, cave pattern, recharge, chemical tracer, vadose branchwork, water table cave Received 28 August 2020; Revised 10 December 2020; Accepted 10 December 2020

Citation: González-Ramón A., Jódar J., Samsó J.M., Martos-Rosillo S., Heredia J., Zabaleta A., Antigüedad I., Custodio E. and Lambán L.J., 2020. Hydrometeorological factors determining the development of water table cave patterns in high alpine zones. The Ordesa and Monte Perdido National Park, NE Spain. International Journal of Speleology, 49 (3), 249-270. Tampa, FL (USA) ISSN 0392-6672 https://doi.org/10.5038/1827-806X.49.3.2346

\section{INTRODUCTION}

In recent decades, some research has shown that the distribution and organization of the explored conduits in a karst system follow just a few patterns. They are related to the water table position and its temporal evolution, the type of aquifer recharge, the density of the fractures, the geological structure and, to a less extent, to porosity of the rock (White, 1988; Ford \& Williams, 2007; Palmer, 2007; Audra \& Palmer, 2011). Audra and Palmer (2015) summarized the processes controlling the genetic models of the caves in only three classes: the geological setting, the aquifer recharge pattern and the time.
According to Palmer (1991), the type of recharge in karst aquifers and the type of dominant porosity have a significative influence on the saturation state of the water circulating through the karst conduits and, therefore, in the patterns of the corresponding caves. Palmer classifies the observed patterns in five types: branchwork, network, anastomotic, ramiform and spongework. All of them are conditioned by (1) the dominant type of groundwater recharge, which may conceptualized as point, diffuse and hypogenic, and (2) by the dominant type of porosity, which can be classified as bedding, parting and intergranular.

Audra and Palmer $(2011,2015)$ differentiated two types of epigenic caves in relation to their vertical 
cave patterns: looping caves and water table caves (Fig. 1). Shafts and canyons develop in the vadose zone (VZ), but in the deepest zone, the looping caves are characterized by both a permanently saturated phreatic zone and an epiphreatic zone where large water table variations may occur. From a functional point of view, both zones are characterized by the existence of permanent springs and "trop pleins", respectively, with a very irregular discharge pattern. The water table caves (WTC) are associated with diffuse recharge processes. These caves normally present a well-developed epikarst zone which is often associated to the presence of an often lowpermeability layer resting above the permeable rocks. In consequence, the WTCs present a complex VZ, with caves of dominant vertical development that change their inclination to much less sloping transects in the

Irregular recharge

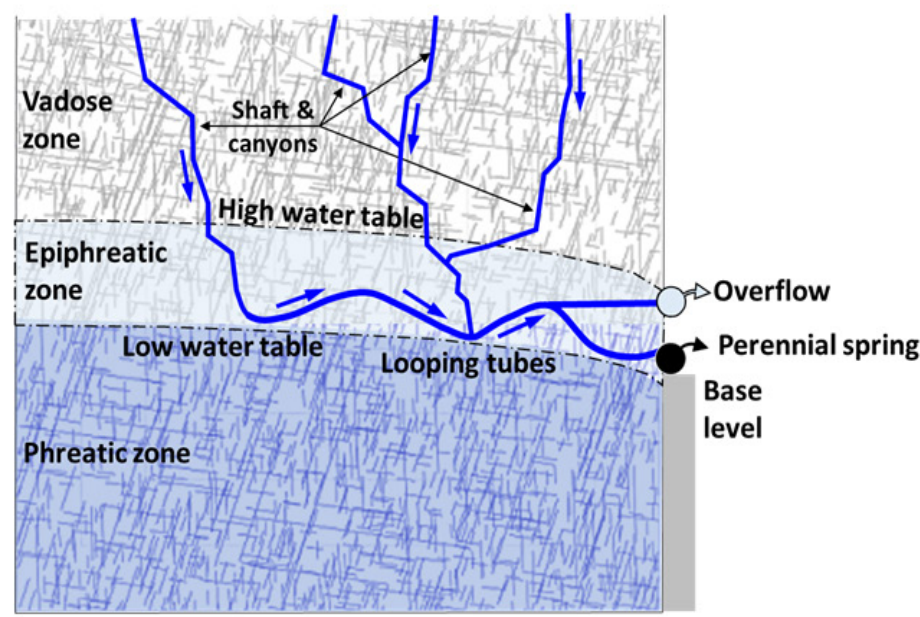

deepest zones. Such conduits present a horizontal shape which is simpler than those of the looping caves. They serve as water collectors that guide the drained groundwater to the springs. These springs are permanent and less variable than the others.

Despite the simple epigenic cave classification of Audra and Palmer $(2011,2015)$ and Jouves et al. (2017) observed that some of them may contain polygenic cave networks within, which may be caused by changes in the boundary conditions (e.g., levels with permeability differences in the unsaturated zone). With this in mind, the cavities can be classified into four basic patterns: (1) vadose branchwork, (2) water table caves, (3) looping caves, and (4) angular mazes. The first three are related to epigenic caves and the latter, in general, with hypogenic cavities, with some exceptions (Sauro et al., 2020).

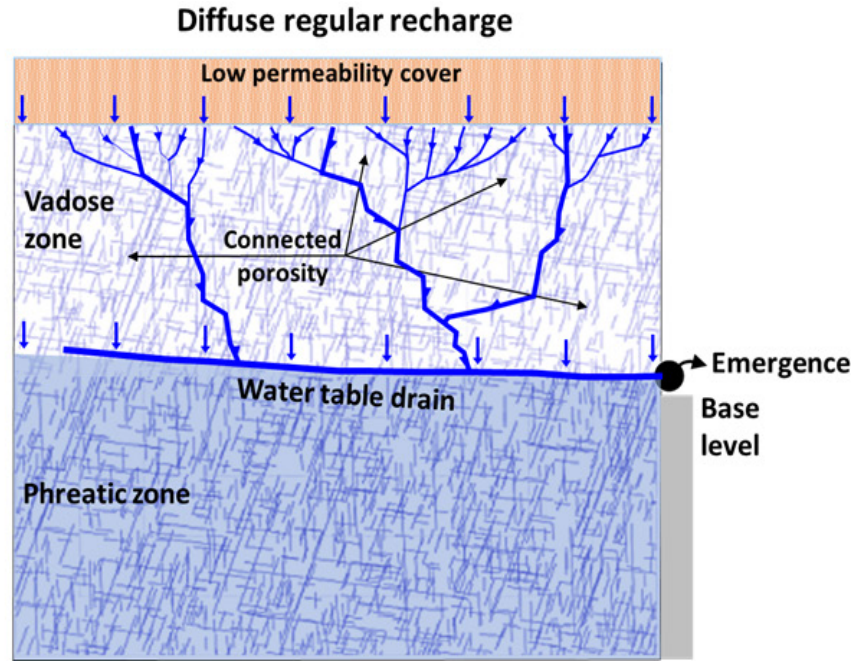

Fig. 1. Morphological differences and type of recharge for looping caves (left panel) and water table caves (right panel). Modified from Audra \& Palmer (2015).

In the $\mathrm{VZ}$, the patterns generated are of the branched type. However, these typically vertical development patterns can be distorted if there are important semipermeable levels that hinder the water flow (Sauro et al., 2012). Nevertheless, the pattern development of these karst networks depends greatly on the type of recharge, which is different in the extreme cases of (1) large water volume inflow in the system with a fast-percolating velocity as a result of variable intensity precipitation events, and (2) low diffuse steady inflow to the system. In the first case, when the incoming = recharge reaches the phreatic zone, it in turn generates groundwater level fluctuations in the epiphreatic zone. These recharge fluctuations propagate through the aquifer system towards the discharge point, causing groundwater flows within the conduits with an often-turbulent flow regime, thus generating a highly variable spring discharge scheme (Jennings, 1985; Gabrovšek \& Peric, 2006; Prelovšek, 2009, and others). In this case, the conduits generated in the epiphreatic zone present a looping trace (Fig. 1-left) with an internal morphology similar to that of the conduits in the phreatic zone, a low topographic slope and a cross-section of lenticular, elliptical or semi-circular shape (Audra \& Palmer, 2011). In the second case, since there are no huge level variations in the phreatic zone, neither the epiphreatic zone nor the associated looping conduits exist. The advance of erosion or surface karstification in the discharge zones and the tectonic activity may contribute to repeat these two patterns vertically, along with the gradual lowering of the water table. As a result, perched fossil networks remain and are therefore integrated into the VZ (Häuselmann, 2002; Harmand et al., 2017).

The karst caves investigated in high mountain zones are generally epigenetic, thus formed by the meteoric water percolating from above. The infiltrated water tries always to flow downwards through the vadose conduit network until reaching the saturated zone. In such karst systems, the dynamics of accumulation and melting of snow may control the aquifer system recharge (Meeks et al., 2017; Thornton et al., 2019; Jódar et al., 2020), and it might even affect the pattern of the karst drainage network, but this point is still poorly understood.

Most of the caves studied in alpine karst systems usually present cavern patterns characterized by a polygenic network of branchwork type in the VZ that often connect different sub-horizontal levels showing looping patterns (Audra \& Palmer, 2013). This looping structure highlights the existence of groundwater fluctuations driven by epiphreatic floodwater effects (Palmer, 1991; Audra, 1994; Häuselmann et al., 2003), which in turn reflect the recurring 
input of large volumes of water in the karst system percolating from its surface (Gabrovšek et al., 2014). Good examples of such mountain cave settings can be found in the Krubera Cave in the Arabika Massif (Western Caucasus) (Klimchouk et al., 2009), where the upper phreatic tubes could have developed during the Messinian salinity crisis in the Upper Miocene, the Piani Eterni karst system (Columbu et al., 2018) and the Totes Gebirge limestone massif (Plan et al., 2009), in the Eastern Alps, where Häuselmann et al. (2020) dated the beginning of the phreatic tubes speleogenesis during the Upper Miocene and Pliocene, when warm and humid climate conditions occurred in this area (Haenel et al., 1988; Sachsenhofer et al., 2003; Audra et al., 2007). Moreover, most of the studied cave systems in the Alps (Audra et al., 2007, and references therein) were formed probably at a lower altitude than their current one (Frisia et al., 1993; Vosteen et al., 2006). As a result, the speleogenesis of these cave systems was little influenced by the snow cover dynamics. This is the case of the paleoepiphreatic looping caves of the Pannonian karst system in the eastern Alps, where the non glacierized conditions along with a pluvial regime drove the development of a looping cave pattern (Wagner et al., 2011). Similar cases at lower elevation can be found in the Pyrenees (Belmonte \& Sancho, 2012; Calvet et al., 2019; Sartégou et al., 2020).

The highest aquifer karst in Western Europe is located in the Paleocene-Eocene limestones of the Ordesa and Monte Perdido National Park (PNOMP), in the Central Southern sector of the Pyrenees. Here, a number of karst systems progress along the slope and the base of a large glacial cirque. The glacier dynamics generated a very intense erosion process during the Quaternary, especially on the slope where most of the caves are located. As a result, the pre-Quaternary relief was dismantled, even eroding most of the Miocene and Pliocene networks that may have previously existed in the area. Therefore, there is an almost complete absence of sub-horizontal epiphreatic fossil galleries in the karst, and the current draining galleries present a water-table pattern running just a few meters above the saturated zone. These characteristics suggest a more recent cave speleogenesis in Ordesa than that reported in the Alps (Häuselmann et al., 2020). In this line, in the neighboring Cotiella carbonate karst massif, which is located only $25 \mathrm{~km}$ to SE of the study zone, Belmonte and Sancho (2012) dated speleotems in the water-table-cave of "Espluga Alta de Lasgüériz" with and age no older than the Middle Pleistocene (450 ka). These authors supposed a Quaternary age for the formation of the cave predating MIS 12 . The cave pattern generation is likely affected by the water infiltration dynamics from the snow and ice accretion and thawing processes, which characterized the transitional interglacial to glacial climate periods over this geological epoch (Holzkamper et al., 2005; Columbu et al., 2018).

The recharge zone of the karst systems draining the Paleocene-Eocene limestones of the PNOMP is located at elevations between 1,855 and $3,170 \mathrm{~m}$ a.s.1., where it is normally covered by snow during 8 months of the year (Lambán et al., 2014; Jódar et al., 2016). Therefore, it is a perfect natural laboratory for exploring the still unknown relationship between the aquifer recharge processes in alpine environments and the geomorphological pattern of the karstic conduits draining the aquifer, which is the main objective of this study. Additionally, given the significant natural heritage value of the study zone, we have carried out a fine scale geological, geomorphological and hydrogeological characterization, to obtain a detailed picture regarding the hydrometeorological factors determining water-table cave patterns in this alpine area.

\section{STUDY AREA}

The PNOMP is located in the central southern sector of the Pyrenees. With a WNW-ESE orientation, this mountain range is the highest in the Iberian Peninsula (Fig. 2) and has the second highest peak. In the PNOMP, the maximum altitude corresponds to the Monte Perdido Peak (3,348 m a.s.1.), which is the third elevation of the Pyrenees.

From a climatic point of view and according to the Köppen-Geiger classification (Peel et al., 2007), the climate in the study zone is cool, with a dry season corresponding to mild and cool summers. It presents significant altitude thermal variations. At the meteorological station of Góriz Refuge (Fig. 3), located at 2,200 $\mathrm{m}$ a.s.1., for the period 1981-2019, the mean anual temperature was $4.9^{\circ} \mathrm{C}$ and the mean precipitation was $1650 \mathrm{~mm} /$ year. The mean monthly precipitation presents two maxima, in October (220 $\mathrm{mm})$ and in May $(185 \mathrm{~mm})$, and two minima, in February $(80 \mathrm{~mm})$ and in July $(105 \mathrm{~mm})$. The spatial variability of precipitation presents a W-E gradient (Benito Alonso, 2006) due to low pressure atmospheric fronts arriving from the Atlantic Ocean. They are responsible for the main precipitation volumes registered in the PNOMP (Lambán et al., 2015). At the meteorological station, the mean annual frequency of solid (snow) precipitation events is 52 days/year. In general, the snowfall events are registered between October and June (Polo, 2015). The large altitudinal variation range existing in the study area generates spatial variations of temperature and precipitation, with vertical gradients of $-3.3^{\circ} \mathrm{C} / \mathrm{km}$ and $200 \mathrm{~mm} /$ year $/ \mathrm{km}$, respectively.

The geomorphological features of the PNOMP reflect the typical modelling of the high pyrenean mountain zones, dominated by glacial action. Multiple small moraines can be observed, and the large valleys are U-shaped, with close-to-vertical slopes. Moreover, hanging side valleys, snowfields, and glaciers, especially in the northern slopes of the Monte Perdido Peak, characterize the rugged alpine landscape of the study area.

From a geological point of view, the PNOMP is in the central sector of a south-pyrenean range, which is part of the "Sierras Interiores" (Inner Ranges) Structural Unit (Séguret, 1972). The geological structure is formed by an imbricated group of overthrust sheets and associated folds, of carbonate materials. The ages 

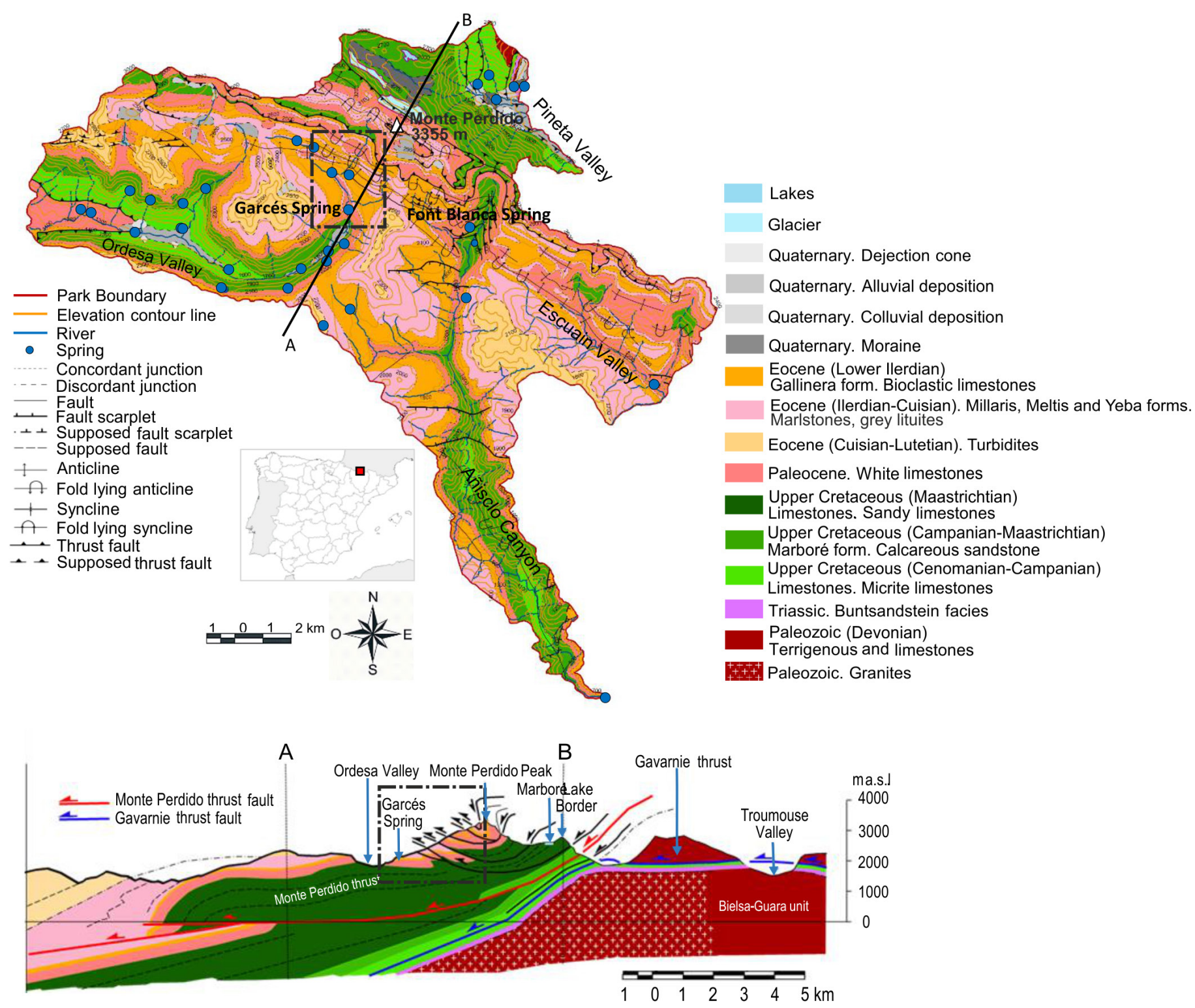

Fig. 2. Location, geological map and geological cross section A-B of the PNOMP (modified from Lambán et al., 2015). The black dashed square shows the study area.

of the materials range from the Upper Cretaceous to the Lower Paleogene, which is linked to the initial emplacement of the Gavarnie Nappe. The system presents a predominantly southern vergence (Séguret, 1972), which is the consequence of the emplacement of the deepest overthrust sheet, which constitutes the antiformal pile in the sense of Choukrune (1989) (Fig. 2).

The Alpine Orogene started in the middle of the Upper Cretaceous. It slowly deformed these materials. The deformation rate increased during the Lower Eocene (Ypresian), so that in the rest of the Eocene, the sedimentary rocks acquired a character of syntectonic sediments.

In the PNOMP, the different materials can be arranged top-down into three large groups as:

1) Gallinero Group-Limestone (s.1.). This has been well studied and differentiated into multiple formations (Robador et al., 2009, 2018; RodríguezFernández et al., 2013; Pujalte et al., 2016). From the bottom to top, the following formations have been described: Salarons dolomites (dolmicrites, dolsparites and well-layered marly dolomites, from the Lower Paleocene), Gallinero limestone (s.e.) (micritic and bioclastic limestone from Upper Paleocene), San Úrbez sandy limestone (calcareous sandstone and sandy limestone from Upper Paleocene), La Pardina sandstone and limestone (quarzitic sandy, carbonated sand and bioclastic limestone with alveolinae of Eocene-Lower Ypresian age; marls and silts with nummulites at the bottom from the beginning of the Eocene), and Góriz limestone (limestone with alveolines and nummulites in the lower part and micritic limestone with silex nodules at the upper part, from the Lower Ypresian).

2) Marboré Group. This is formed by a quite homogeneous group of calcareous sandstone with quartz-arenite and greywacke. These materials outcrop widely in the great escarpments of the Ordesa Valley; their age corresponds fundamentally to the Campanian and Maastrichtian.

3) Cañones Group. This is formed by UpperCretaceous (Santonian) limestone of the Calizas del Estrecho and Marboré Formations.

In the study zone, only the first two groups outcrop (Fig. 3). Other terrigenous formations are arranged progressively and transitionally over them, marking 
the pass from the slow to the fast deformation stages, whilst the nappe of Gavarnie is displaced, and this determines important variations in thickness and bathymetry. These units are integrated by the Metils and the Tobacor formations, and the Hecho group, which are mainly composed of marly-limestone, sandstones and turbidites, respectively.

The stratigraphic sequence of the study area begins with the low permeability sandstone of the Marboré Formation. Over these materials lie those of the Gallinero group, with a first dolomitic layer of $\sim 50 \mathrm{~m}$ thickness of the Lower Paleocene Salarons
Formation, with a low degree of karstification and a low permeability due to the dolomitic and clayey composition. These materials are covered by the bioclastic and silex limestone of the Upper Paleocene and Eocene, 200 to $300 \mathrm{~m}$ thick, but in the study zone this is much thicker due to the stacked overthrustsheet structure that generates vertical developments close to 1000 m (Lambán et al., 2015, 2019) (Fig. 4A). These materials are highly karstified and have a great permeability. In fact, they contain the largest springs in the PNOMP (Ríos-Aragüés, 2003; Lambán et al., 2015, 2019).

Legend:
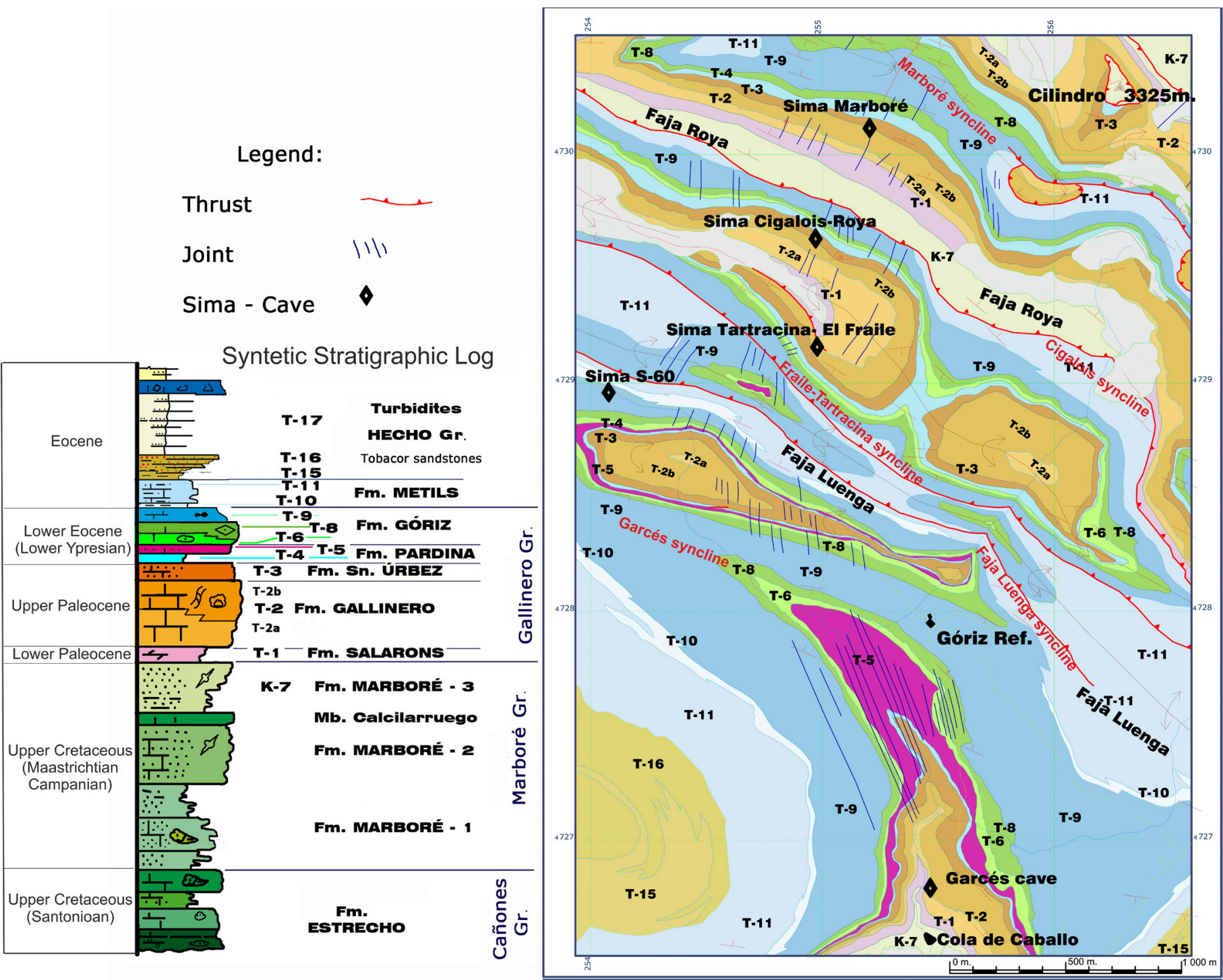

Fig. 3. Geological map (1:5000 scale) and geological column of the study area.

All the units of the above-described stratigraphic sequence are structured in a set of overturned folds, reverse fault and overthrusts, so that the same structure is repeated several times vertically. Six folded structures can be identified where the karstified carbonates of the Gallinero Group are located. The folds have a vertical $\mathrm{N}$ flank that is normally inverted, whereas the S flank gently dips to the N. This disposition allows groundwater storage in the syncline structures due to the differences in permeability caused by the Marbore Sandstone.

The hydrogeological basin has two main groundwater discharge points, the Garcés and the Font Blanca springs. The former is the overflow point of the Garcés
Cave, which forms the Cola de Caballo Waterfall a few meters ahead (Fig. 4B, C). The latter spring is located at the headwaters of the Añisclo Valley (Fig. 2 and 4D). In both cases, the springs are located in the contact between the karstified Paleocene-Eocene materials of the Gallinero Group and the sandstone of the Upper Cretaceous Marboré Formation, which is a low permeability relative to the karstified limestones.

The meteoric water enters the system through the most conductive karst features, including swallow holes and wide fractures, but also through the extense network of joints and fractures that is distributed throughout the study zone (see Supplementary Material). 


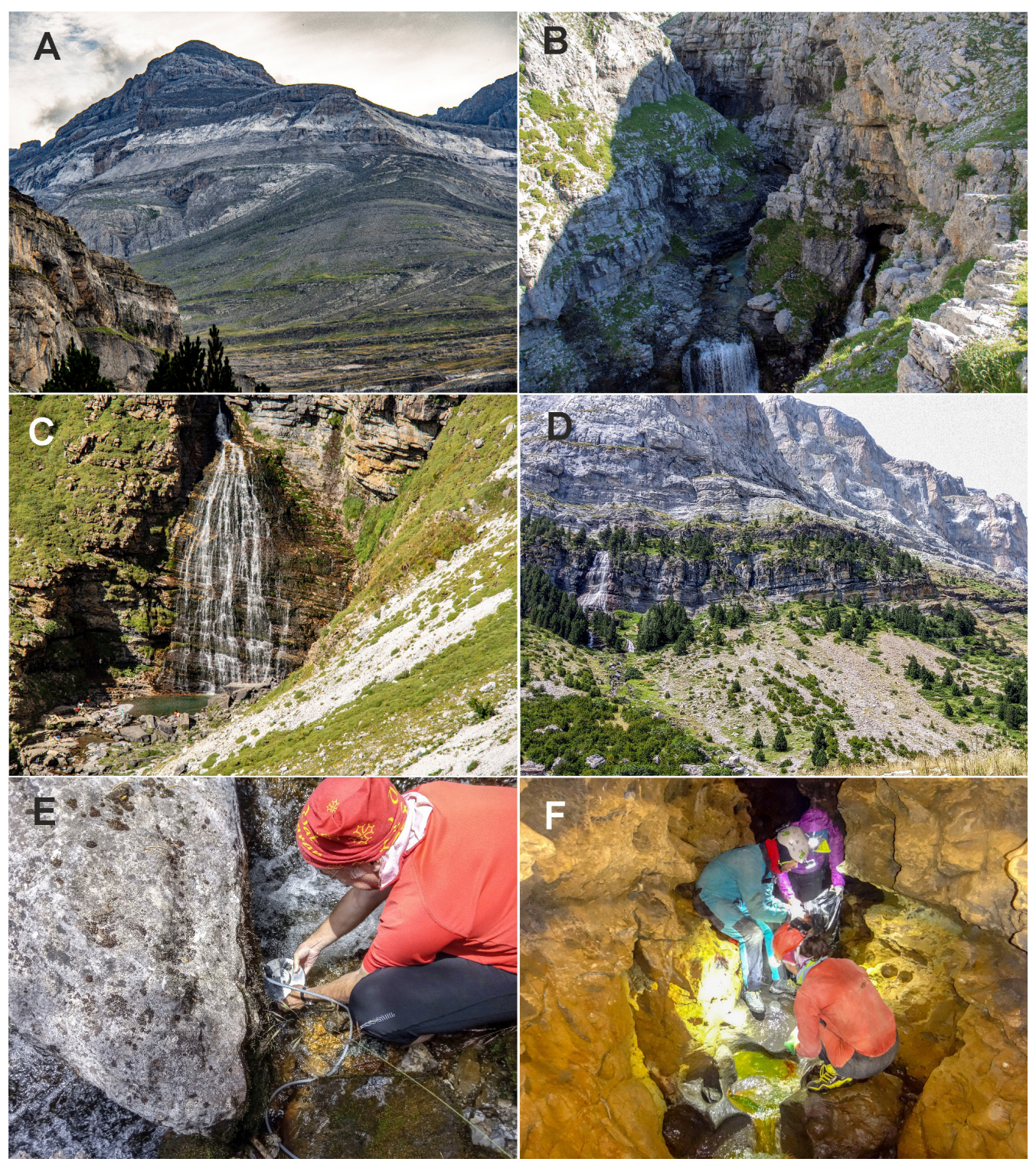

Fig. 4. A) Stacking of folded structures in the study area; B) Discharge of the Garcés Cave and canyon carved above the Cola de Caballo Waterfall (C); D) Discharge area of the Font Blanca Spring; to the left of the picture the homonymous waterfall after the spring discharge point; E) Installation of the GGUN-FL30 fluorimeter in the Font Blanca Spring; F) Uranine injection at the bottom of the shaft in the M-1 entrance to the Marbore System (August 2019).

In the study zone, six syncline structures can be observed. From bottom to top, these are (1) Garcés, (2) Faja Luenga, (3) Fraile-Tartracina, (4) La RoyaCigalois, (5) La Faja Roya-Marboré and (6) Cilindro de Marboré (Fig. 3).

\section{MATERIALS AND METHODS}

\section{Geological cartography}

A detailed map (scale 1:5000) has been made (Fig. 3) to define with precision the different types of joints, the existing caves and the geological structure of the study area. It is based on the 1:25000 regional geological maps of the PNOMP (Robador et al., 2010, 2018), which allows drawing detailed geological crosssections on which the vertical traces of the mapped karst systems can be projected.

\section{Revision of the available documentation of the mapped karst systems}

During this study, the information collection has been carried out to integrate all the available information generated by the different speleological groups during the exploration of the different karst systems identified in the study zone. Their analysis has allowed us to make a good description of six cave systems, namely Marboré, Roya-Cigalois, Fraile-La Tartracina, Sima S-60, Garcés, and Font Blanca. The main characteristics of these systems are summarized in Table 1 and described in the next section.

The projection of the mapped topography corresponding to the studied systems are shown in Figure 5. In all cases, a predominantly NW-SE orientation of the karstic conduits can be observed, except in part of the Garcés system, which also shows a large sector developed along the NNE-SSW orientation.

\section{Tracer tests related with the Garcés System}

To find the hydrological connections between the inventoried swallow-holes and shafts and the springs of the PNOMP, different speleological groups have performed various tracer tests in the study area. Unfortunately, the technical information of these tracer tests is sparse and often incomplete. Table 2 
Table 1. Main characteristics of the studied caves

\begin{tabular}{|l|c|c|c|c|c|}
\hline \multicolumn{1}{|c|}{ System } & Exploration year & $\begin{array}{c}\text { Exploration } \\
\text { group }\end{array}$ & $\begin{array}{c}\text { Surveyed } \\
\text { length (m) }\end{array}$ & $\begin{array}{c}\text { Suveyed } \\
\text { depth (m) }\end{array}$ & Reference \\
\hline Marboré & 1953,1985 & A, B & 4074 & 401 & Puch (1998) \\
\hline La Roya-Cigalois & 1957,1962 & A & -- & 143 & GE OTXOLA (2019, 2018) \\
\hline Fraile-Tartracina & $1980-1984$ & B & 4506 & 415 & Puch (1998); GE OTXOLA (2018) \\
\hline S-60 Shaft & $1960-1980$ & C & 766 & 103 & GE de Badalona (1963) \\
\hline Font Blanca Cave & $2010,2012,2020$ & D & 800 & 35 & SCC (2012) \\
\hline Garcés Cave & 2013 & E & 3024 & 125 & Ruiz Zubikoa (2017); GE OTXOLA (2019, \\
2017, 2016, 2015)
\end{tabular}

(A) SC Alpin Languedocien (Montpellier); (B) GS Pyrénées (Toulouse); (C) GE de Badalona; (D) SC du Comminges; (E) GE Otxola.

shows the basic and contrasted information of the tracer tests performed in the karst systems of the study area.

On August 5, 2019, members of the Speleological Group Otxola and the Geological and Mining Institute of Spain (IGME) performed a multi-tracer test in the study area, injecting uranine, eosine, naphtionate and amino-G into the karst systems of Marboré, Cigalois, S-60 and Tartracina (Fig. 6, Table 2), one in each location. Two fluorometers GGUN-FL24 were installed in sump-1 (locally known as Silvia Coll's Sump) of the Garcés Cave (Figs. 6 and 7) to differentiate simultaneously the four injected tracers, because the GGUN fluorometer can only detect three tracers at the same time. A GGUN-FL30 fluorometer was also installed in the Font Blanca Spring (Fig. 6). This device was prepared to distinguish between uranine, eosine and amino-G.
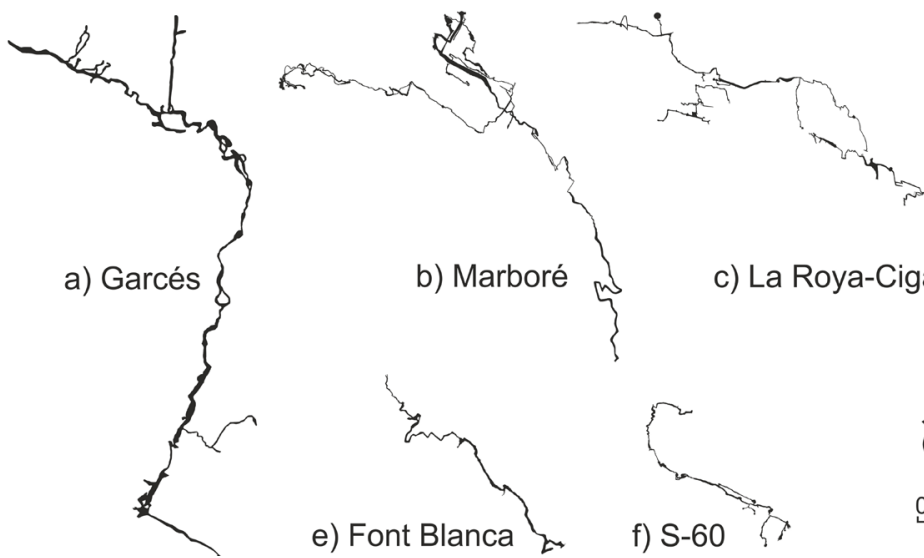

Fig. 5. Plan of the layout of the studied karst systems. Their main characteristics are reported in Table 1.

Table 2. Technical details of the tracer tests performed in the karst systems of the study area.

\begin{tabular}{|l|c|c|c|c|}
\hline \multicolumn{1}{|c|}{ Tracer injection point (karst system) } & Year & Tracer & Injected mass (kg) & Tracer discharge point \\
\hline \multirow{4}{*}{ Marboré } & 1954 & Uranine & 5 & Not detected \\
\cline { 2 - 5 } & 1955 & Uranine & 10 & Garcés spring \\
\cline { 2 - 5 } & 1987 & Uranine & 0.5 & Not detected \\
\cline { 2 - 5 } & 1990 & Uranine & 1.5 & Not detected \\
\cline { 2 - 5 } & 2019 & Uranine & 1 & Garcés and Font Blanca \\
springs
\end{tabular}

\section{Monitoring of the Garcés Karst System}

To measure the water level, temperature and electric conductivity variations in groundwater along the Garcés karst system, two CTD-Diver ${ }^{\circledR}$ sensors (van Essen Instruments, 2016) were installed in sump-1 and sump-3, respectively. In addition, and close to each CTD, a BaroDiver ${ }^{\circ}$ sensor was installed to control the variations of the air pressure and temperature inside the cave.

\section{Autocorrelation and cross-correlation}

The autocorrelation function characterizes the linear dependency of successive values over a period.
This function is represented by the correlogram that draws the memory of the system $C_{X}(k)$. The shorter the influence of a given event on the time series, the steeper the slope of the auto-correlation function $r_{X}(k)$ is, and conversely.

$$
\begin{gathered}
r_{X}(k)=\frac{C_{X}(k)}{C_{X}(0)} \\
C_{X}(k)=\frac{1}{N} \sum_{j=1}^{N-k}\left(X_{j}-\bar{X}\right)\left(X_{j+k}-\bar{X}\right)
\end{gathered}
$$

where $N, X_{j}$, and $X$ are respectively the length, the $j^{\text {th }}$ term and the average value of the time series $X(\mathrm{t})$, and 

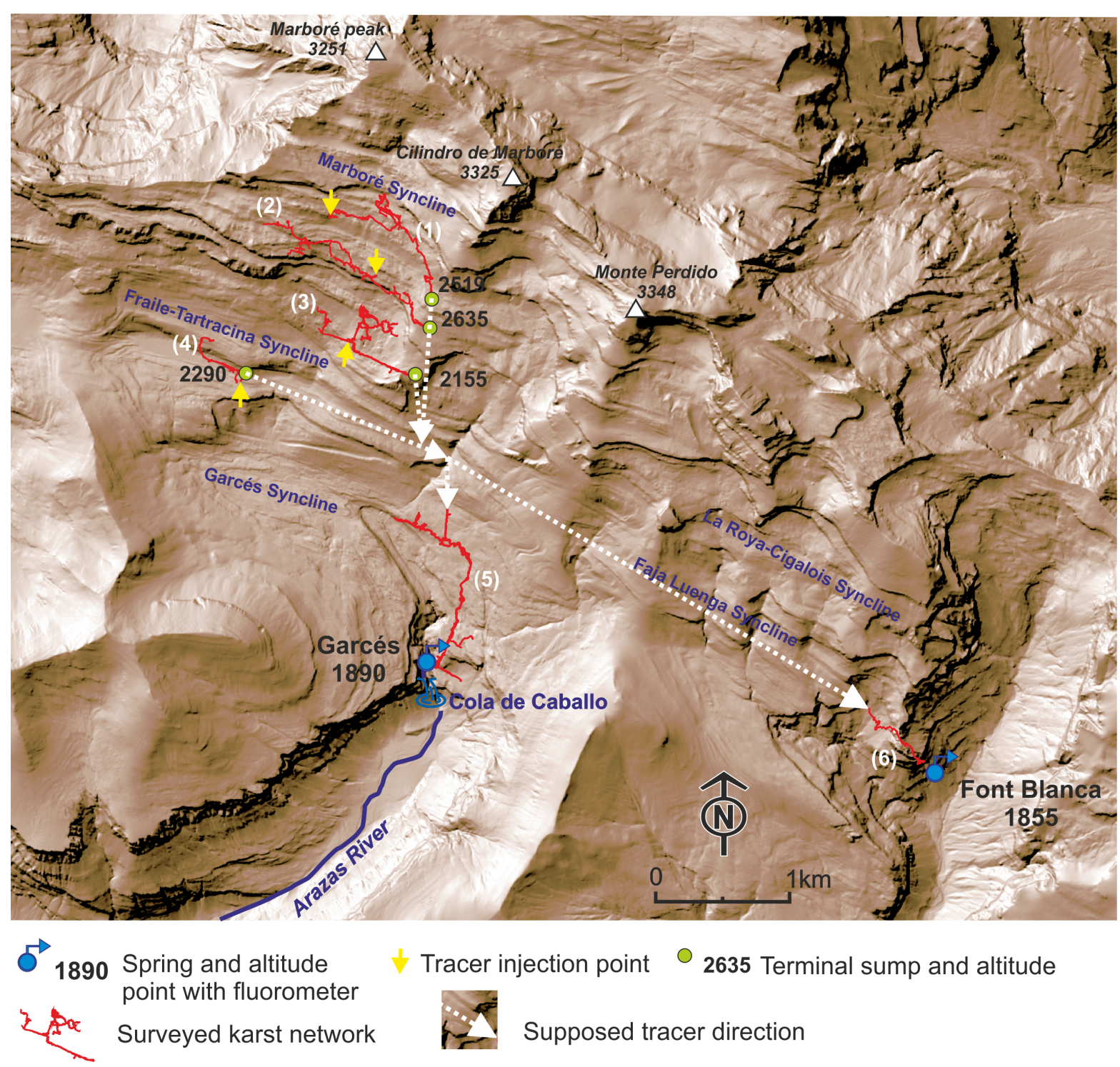

Fig. 6. Karst systems studied in the area. The numbers correspond to (1) Marboré, (2) La Roya-Cigalois, (3) El Fraile-La Tartracina, (4) S-60, (5) Garcés, and (6) Font Blanca. The short arrows indicate the position of the tracer injection points of this work, and the circles mark the position of the mapped terminal sump for the corresponding karst system. Dashed arrows show a plausible migrating path for the tracer from the injection poins to the Garcés karst system.

$k$ is the time lag characteristic of each value, i.e., a response or activation feedback time.

Cross-correlation is used to determine the relationship between two variables $\mathrm{X}$ and $\mathrm{Y}$. In the case of karst hydrology, they often describe inputoutput relationships as for rainfall-discharge or groundwater level variations. The cross-correlation is represented by a cross-correlogram, $r_{X Y}(k)$, that defines the system's response to an external action, and it is formally defined as

$$
\begin{gathered}
r_{X Y}(k)=\frac{C_{X Y}(k)}{\sigma_{X} \sigma_{Y}} \\
C_{X Y}(k)=\frac{1}{N} \sum_{j=1}^{N-k}\left(X_{j}-\bar{X}\right)\left(Y_{j+k}-\bar{Y}\right)
\end{gathered}
$$

where $C_{X Y}(k)$ is the cross-correlogram function and $\sigma_{X}$ and $\sigma_{Y}$ are the standard deviations of the time series $X(\mathrm{t})$ and $Y(\mathrm{t})$, respectively. If the input signal $X(\mathrm{t})$ into the aquifer corresponds to a random variable, then the cross-correlation function corresponds to the system response function. Mangin (1984) and Padilla and Pulido-Bosch (1995) analize the shape of
$r_{X}(k)$ and $r_{X Y}(k)$ for different common situations in the framework of karst groundwater hydrology.

\section{RESULTS}

\section{Description of karst systems}

In this section, the main aspects of three karst systems in the studied area, for which good cartographic information has been obtained, are described. Their main features are interpreted considering both the different geological formations they cross, and the prevailing hydrogeological conditions under which the karst conduits have developed.

\section{The Garcés Cave}

The entrance to the Garcés Cave is interpreted as an old discharge point that remained perched and that was possibly fed, at the beginning, by the fossil gallery with a N120E direction (Fig. 7). During low flow periods, groundwater overflowing sump-1 discharges into the Arazas River through the Garcés Spring, which is a few meters away from sump-1. During high flow periods, the system also discharges through a 


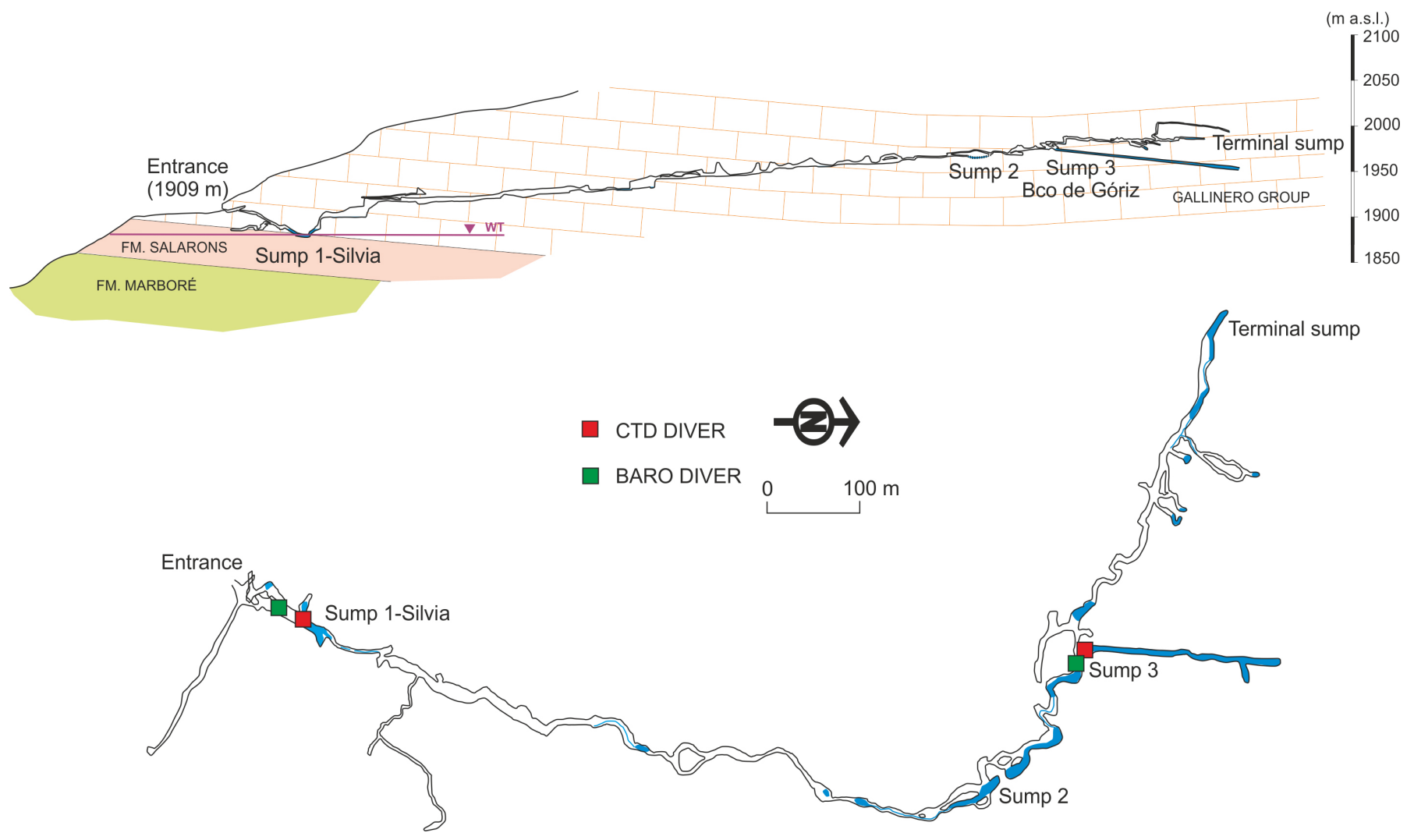

Fig. 7. Plan and cross-section of the Garcés Cave with the location of monitoring points (modified from GE Otxola, 2017).

"trop plein" (overflow) group located at different levels on the left bank of the Arazas River.

The base of the sump-1 discharge point corresponds to the contact between limestone of the Gallinero group and dolomites of the Salarons Formation (Figs. 3 and 7). From this point on, groundwater flows over the escarpment formed by the Marbore sandstone and only some meters ahead feeds the "Cola de Caballo" Waterfall (Figs. 4B and 6).

The water table must correspond with the permanent discharge point at the bottom of the Arazas River canyon located around 10-15 meters below the level of sump-1. This sump has a length of $57 \mathrm{~m}$ and a maximum depth of $12 \mathrm{~m}$ (Ruiz Zubikoa, 2017). After the sump, the main gallery continues in the $\mathrm{N} 10 \mathrm{E}$ direction, and later draw an arc that turns towards the W, similar to the layout of the surface channel and the imprint of the glacial cirque. After the bend, a gallery with $\mathrm{N}$ direction, matching approximately the "Barranco de Góriz (Góriz Brook) layout”, connects with the main conduit system through sump-3. This gallery provides the highest inflow to the Garcés Cave. From this point upstream, the conduit of the main system receives several lateral tributaries from the North. They come from a set of conduits with $\mathrm{N}$ orientation and a tendency to follow the dipping direction of the stratification.

The Garcés syncline collects part of the discharges from the perched saturated zones in the core of the successive synclines above it, as revealed by the different tracer tests conducted in the study zone (ENSG, 1990) (Table 2).

\section{The Font Blanca Cave}

The entrance of the cave is the surgence of the Font Blanca Spring (1,855 $\mathrm{m}$ a.s.1.). The water immediately falls down the cliff that forms the right bank of the Añisclo Canyon (Fig. 4D). The spring lies about $20 \mathrm{~m}$ above the contact between the Salarons and Marbore formations (Fig. 8). The explored cave is a unique, semi-flooded $800 \mathrm{~m}$ long passage, which extends in the NW-SE direction following the core of the Faja Luenga syncline. The entire cave is carved in the Solarons Formation.

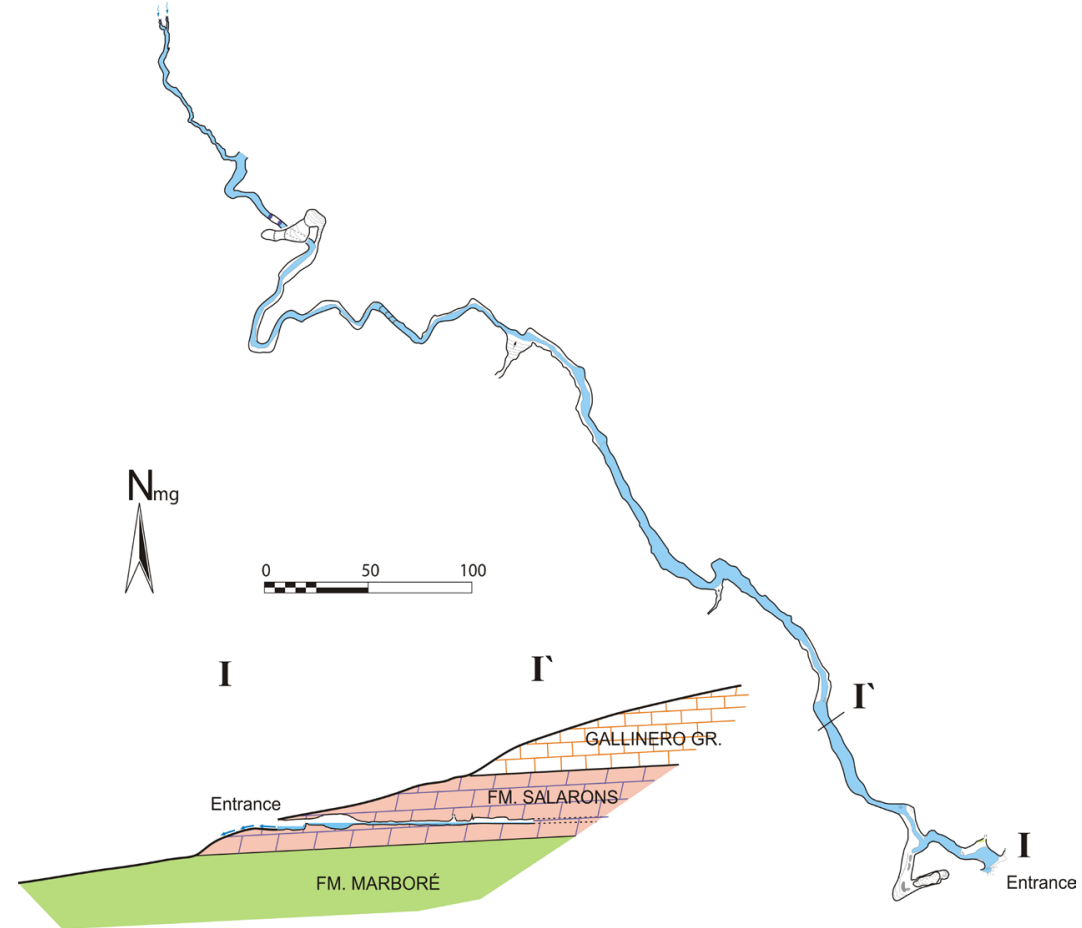

Fig. 8. Plan and partial cross-section of the Font Blanca Cave (modified from Spéléo Club du Comminges, 2010-2012). 
The Sima S-60 system

The cave has two close entrances located at 2,342 m a.s.1. The entrance 1 is a sinkhole that in low water absorbs a permanent flow of about $5 \mathrm{~L} / \mathrm{s}$. The cave continues through a succession of shafts until reaching a sub-horizontal gallery at $-50 \mathrm{~m}$, with $250 \mathrm{~m}$ of development in NW direction. The gallery descends another $50 \mathrm{~m}$ with various drops and turns, first towards the $\mathrm{N}$ and then towards the $\mathrm{SE}$, in the opposite direction (to Garcés spring) and ending shortly afterwards in a sump at $-103 \mathrm{~m}(2,239 \mathrm{~m}$ a.s.1.). The entire cave is developed in carbonate rocks of the Gallinero Group (Fig. 9).

\section{The Fraile-La Tartracina system}

Three entrances to the Fraile-La Tartracina system are known: R31 or the Tartracina Shaft $(2,570 \mathrm{~m}$ a.s.1.), R17 (2,526 m a.s.1), and R3 or Fraile Cave (2,520 $\mathrm{m}$ a.s.1.), where the exploration began. The three entrances are hosted in the Gallinero limestone and consist of a succession of vertical shafts. The union between the shafts coming from R3 1 and R17 should mark the intersection point with the first overthrust fault crossed by the main cave conduit. From this point onwards, the cave intersects the dolomitic level of the Salarons Formation. Afterwards, and before reaching the large collector system, the main conduit might go across the second overthrust fault (Fig. 10).

The large collector consists of a wide rectilinear and semi-flooded gallery that develops through the epiphreatic level above the possible saturated zone of Faja Luenga syncline, until reaching the terminal sump at 2,155 $\mathrm{m}$ a.s.1. (Fig. 10). This point is connected with the Garcés sump as shown in the tracer test conducted in 1966 (Table 3; ENSG, 1990). In general, the conduits follow and adapt to the N115E direction defined by the syncline axis, with some passages developed in the perpendicular direction. These last passages follow the dipping direction of the stratification (N25E) on the synclinal flanks. Possibly the connections between the different systems are produced following this direction.

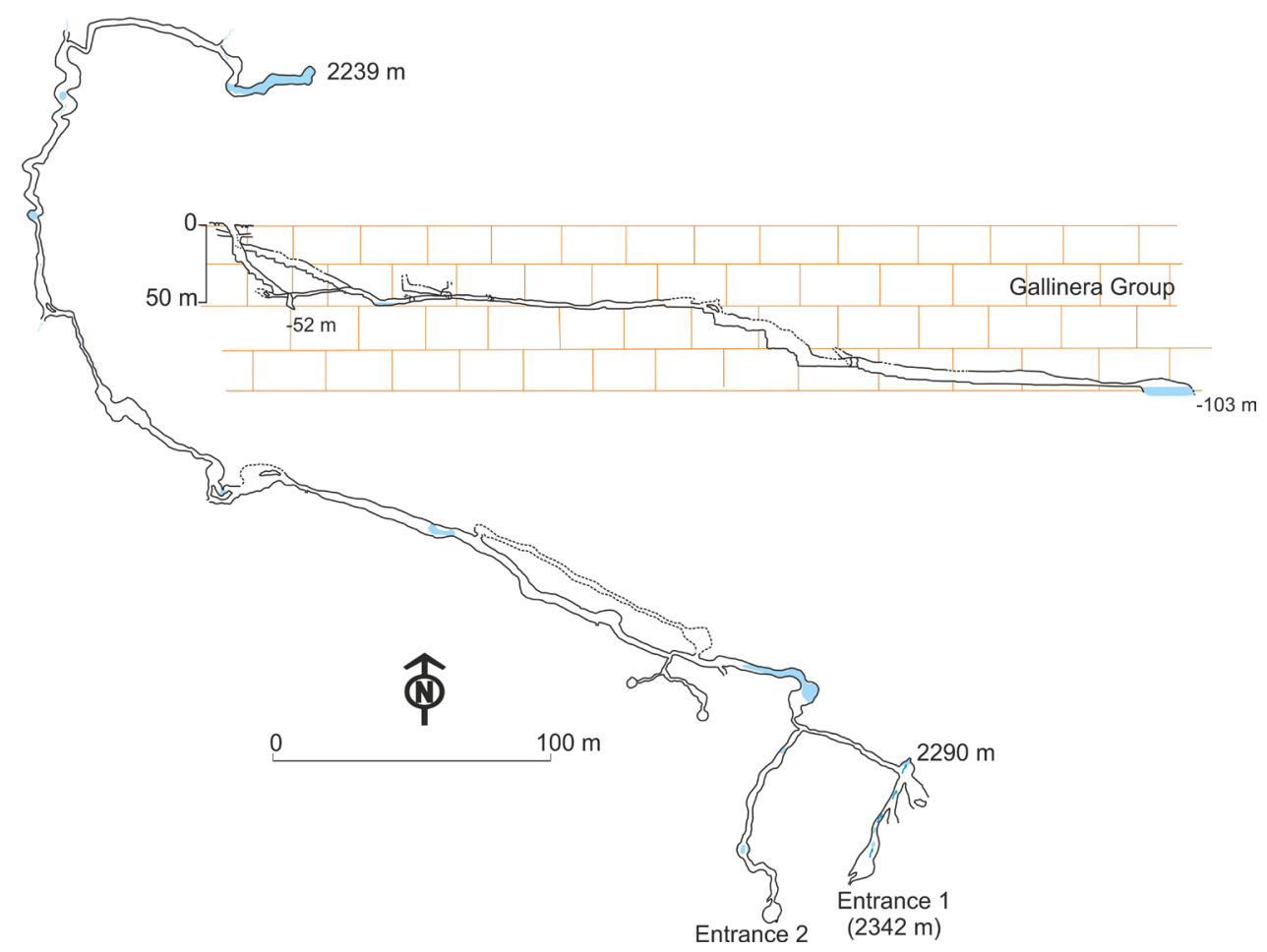

Fig. 9. Plan and partial cross-section of the Sima S-60 system (modified from G.E. Pyrénées, 1988).

\section{The La Roya-Cigalois System}

This system is an interconnected group of caves. Their maps are not considered finished since there are no cross-sections (Fig. 11). Eight entrances to the system are known located at elevations between 2,846 $\mathrm{m}$ (M45) and 2,716 $\mathrm{m}$ (R73-74). The caves are developed in the limestones of the Gallinera Group following galleries with $\mathrm{N} 125 \mathrm{E}$ direction, according to the direction of the structures. The galleries develop from $2,846 \mathrm{~m}$ to $2,635 \mathrm{~m}$ ending in a terminal sump. The tracer tests (ENSG, 1990) showed that the water of this system mixes with those from the Marbore system and reach the Garcés Cave in a similar time.

\section{The Marboré System}

The Marboré cave system has two entrances M1 (2,920 m a.s.1.) and M2 (2,870 m a.s.1.), locally known as "Las Vedettes" and "Los Amigos", respectively. They are located in the dolomitic Salarons Formation and in both cases developed through vertical shafts until reaching the contact with the low permeability sandstones of the Marboré Formation (Fig. 12). At this point, the conduits become narrow and sub-horizontal, present intersections with some overlapping fossil galleries and receive small groundwater contributions. The conduits go through the contact between both formations. The directions of the structural axis alternatively shift between the direction marked by the syncline of the Faja Roya-Marboré (N110$125 \mathrm{E}$ ) and the direction of the dipping sedimentary layers on the flanks (N25-30E). Both directions are perpendicular to each other until reaching the conduits that connect with the M2 entrance. From this point, the size of the gallery increases and crosses 
I R31 Entrada Tartracina
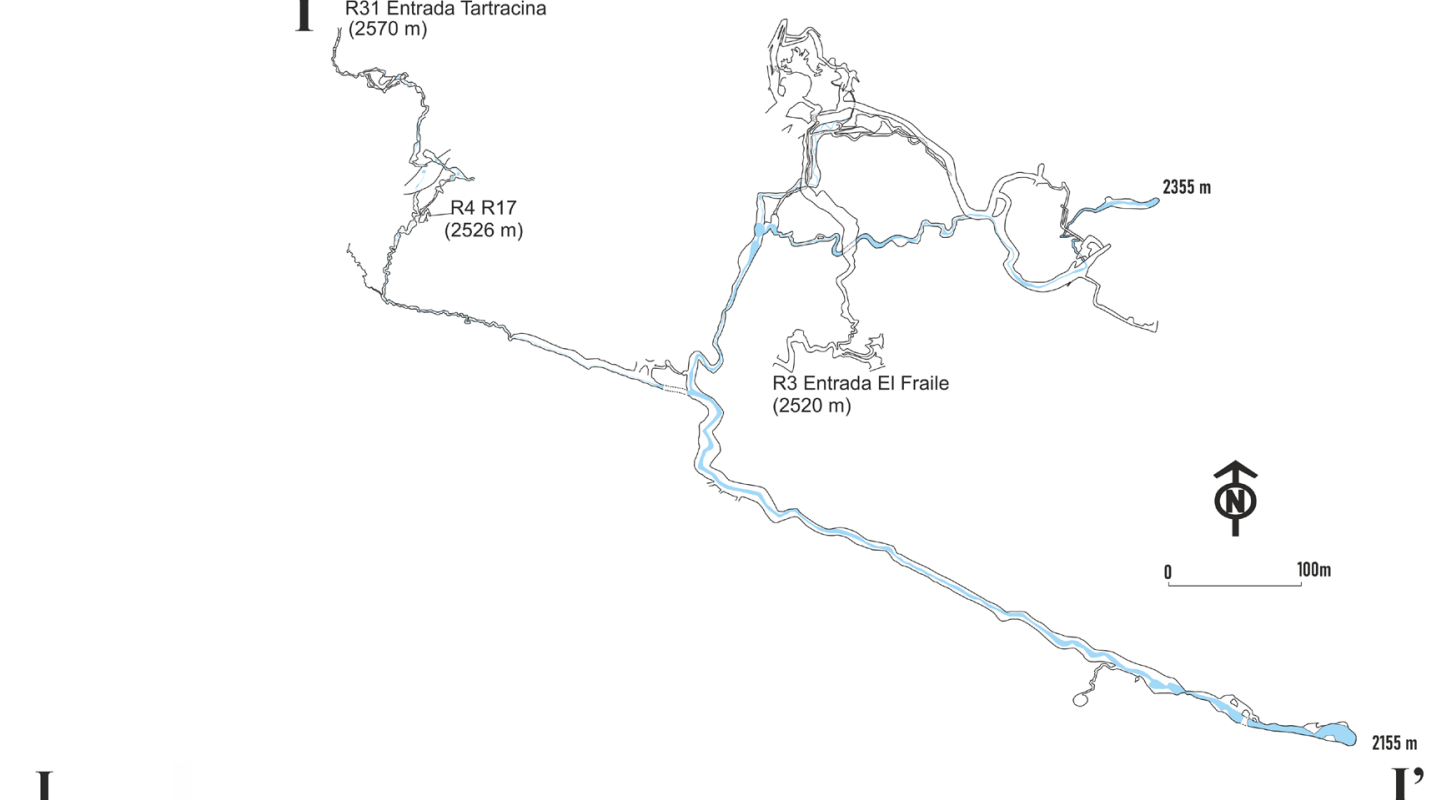

I

I'

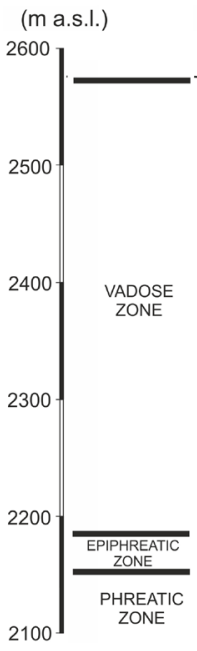

R31 (2570 m)

Fig. 10. Plan and cross-section of the Fraile-La Tartracina System with the interpretation of the lithologies intersected along the cave trace (modified topography of the Group de Spéléologie Pyrénées de Toulouse). The different morphological zones are defined in terms of the spatial distribution of conduits patterns along the system, and the observed position of both the water and the corresponding vertical variations.

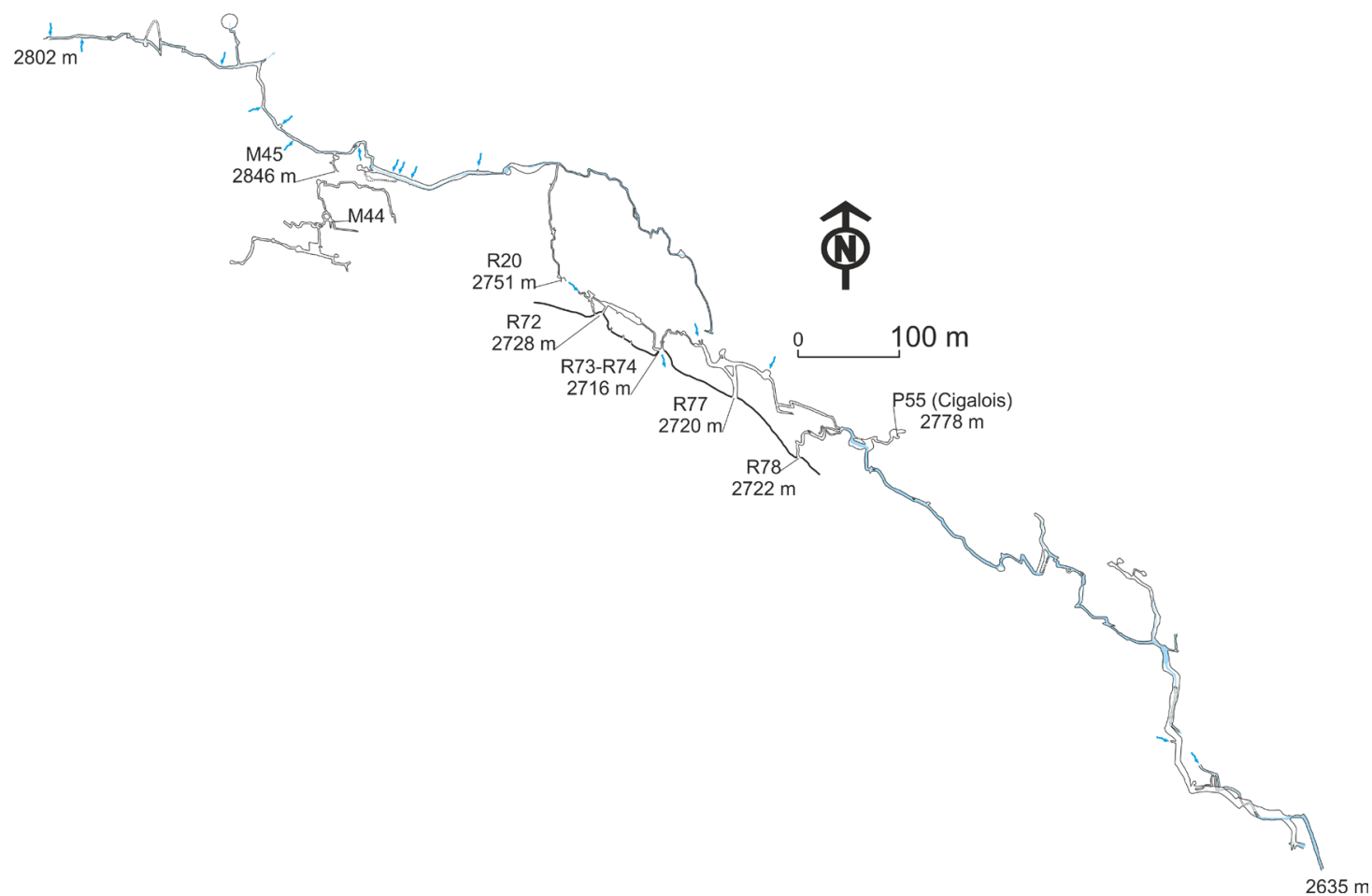

Fig. 11. Map of the La Roya-Cigalois System (modified from SC Alpin Languedocien de Montpellier). 
the contact with the marly sandstone of the Marboré Formation, in which the conduit passes up to reaching the big shaft at a depth of $111 \mathrm{~m}$. At the top of this shaft, the overthrust fault plane marking the passage from the low permeability sandstone of the Marbore Formation above with the underlying high permeability limestone of the Gallinero Group is located. At the bottom of the shaft, a large subhorizontal collector is reached, which runs through the epiphreatic zone ending in the terminal sump at 2,519 $\mathrm{m}$ a.s.1. (Fig. 12). The direction of the collector gallery turns gradually from that of the structural axis to $\mathrm{S}$. The water level in the terminal sump should mark the position of the phreatic level or of the epiphreatic galleries over the perched aquifer formed in the karstified limestone of the Roya-Cigalois syncline (Fig. 6), which is in turn drained by the conduit system.

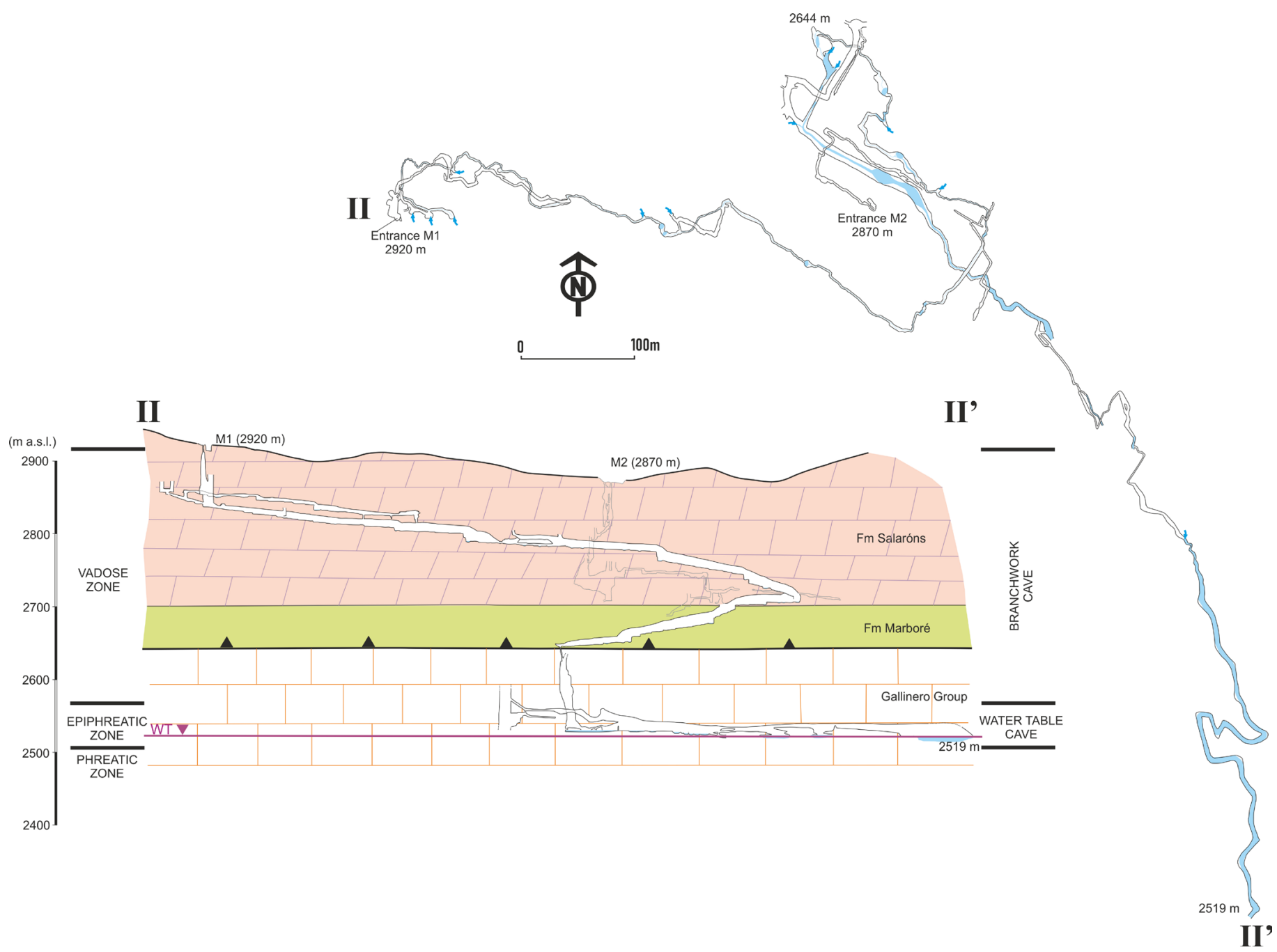

Fig. 12. Plan and cross-section of the Marboré cave system with the interpretation of the lithologies intersected along the trace. The first galleries are dipping towards the east by the contact between the Salarons and Marbore formations and then turn south. Thereafter, the thickness of the Salarons Formation appears exaggerated in the cross-section (modified topography of the GS Pyrénées de Toulouse). The different morphological zones are defined in terms of the spatial distribution of conduit patterns along the system, and the observed position of both the water and the corresponding vertical variations.

\section{Characterization of recharge to the Garcés karst system}

The data recorded by the CTDs installed in the Garcés cave allowed the observation of how recharge controlled the Garcés Spring discharge during the period 2018-2019. The water level variations in sump1 are almost homothetic to those of sump-3 (Fig. 13). This indicates that no significant groundwater contributions fed the system between both control points.

From the temporal variation of the different hydrometeorological variables measured in the Garcés karst system for the period Sep. 2018 - Sep. 2019, five aquifer recharge stages (Fig. 13) can be inferred to describe the hydrogeological system dynamics for a whole annual cycle:
1. Stage 1: The rainfall events generate sudden variations of the groundwater levels, EC (electrical conductivity) and $\mathrm{T}$ (temperature). Furthermore, $\mathrm{EC}$ and $\mathrm{T}$ show a similar behavior, with an increasing trend from the beginning of the stage until September, when both variables stabilize. In this period, the system discharge shows a recession trend, in which the main shafts and conduits of the karst system drain the connected porosity of the aquifer. In October, the intense rainfall events generate both fast recharge entering the system through swallow-holes, and slow recharge entering the system through joints and small fractures. The fast recharge influences the total system flow through the main conduit of the system. During this period, EC in groundwater 
decreased and $\mathrm{T}$ increased, in coherence with the corresponding values in rainfall.

2. Stage 2. This is a transition period. Precipitation is mainly as snow. Only a few fast recharge events occur. Moreover, the in-transit recharge entering the system through superficial joints and small fractures during the previous warm period, continued percolating through the interconnected pores of the system, and finally reaches the phreatic level. Little by little the intransit recharge dominates the whole system discharge. As a result, EC and T in groundwater increase until they stabilize. The EC increase is mostly due to carbonate dissolution induced by soil $\mathrm{CO}_{2}$ and the evapoconcentration effect. The $\mathrm{T}$ increase is due to equilibration with the average local temperature.

3. Stage 3. In this period, there is no fast recharge event entering the system, and the contribution of the in-transit recharge is at most very small. The system discharges groundwater which is stored in the connected porosity of the aquifer and therefore the $\mathrm{EC}$ and $\mathrm{T}$ of groundwater remain steady.

4. Stage 4. This is another transition period. Precipitation is still solid (i.e., snow). Nevertheless, the aquifer recharge process starts, slowly at the beginning and showing a temporal pattern similar to that of atmospheric temperature. This indicates that snowmelt is the source of recharge water. EC

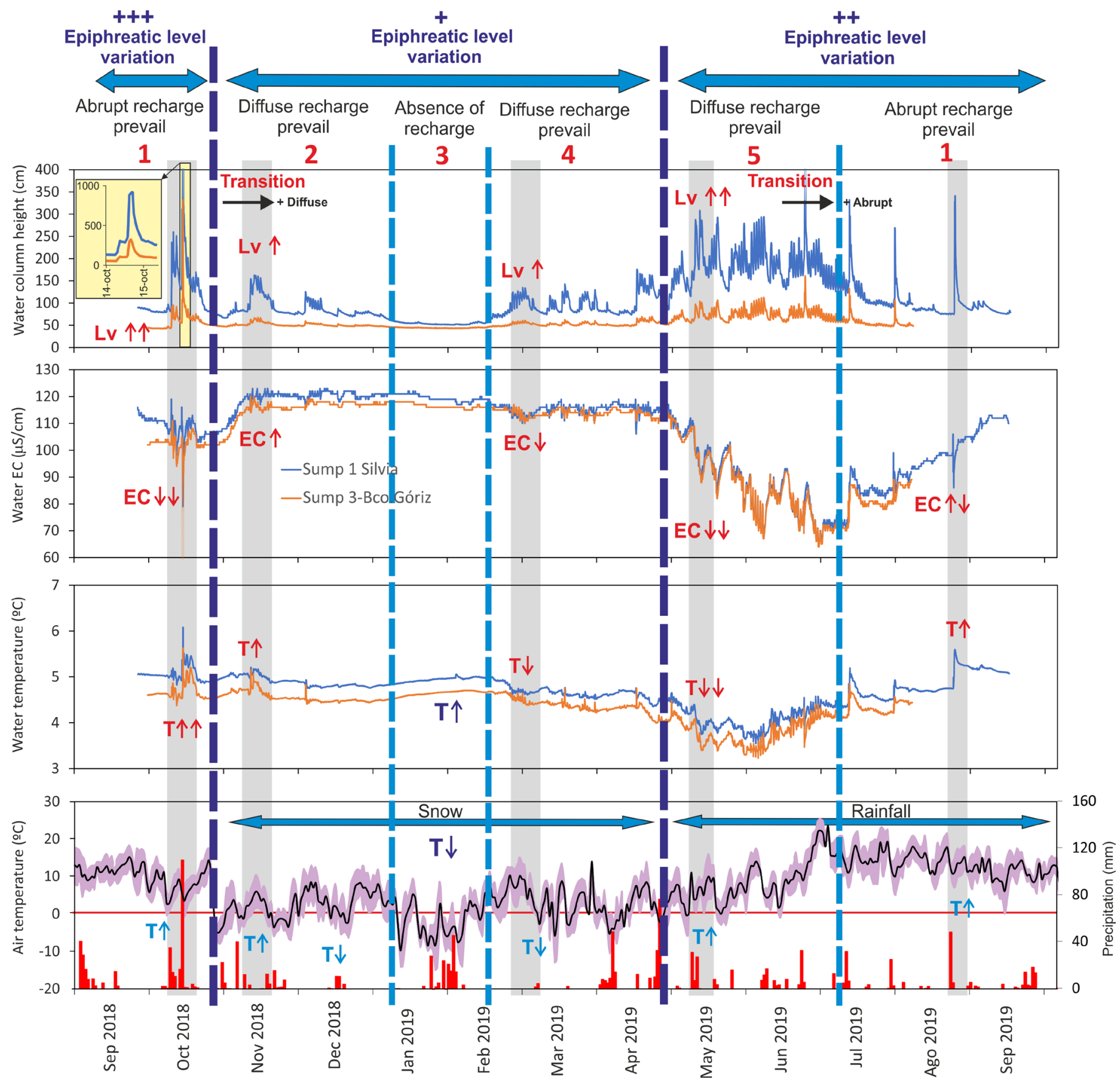

Fig. 13. Variation of groundwater level (top panel), EC (second from top), and T (third from top) observed in the Garcés Cave for the period Sep-2018 to Sep-2019. For each variable, the upper and lower lines correspond to the time series measured in sump-1 and sump-3, respectively. The lower panel shows the evolution of the daily precipitation (columns, in $\mathrm{mm}$ ) and mean atmospheric temperature (line, ${ }^{\circ} \mathrm{C}$ ) measured in the meteorological station of Góriz for the same period. The shaded strip corresponds to the maximum and minimum daily temperature variations. The freezing point $\left(0^{\circ} \mathrm{C}\right)$ is indicated by a horizontal line crossing the panel. The details of the different recharge stages ( 1 to 5$)$ indicated in the figure are explained thoroughly in the text. Grey bars show the different relationships between groundwater level (Lv), EC, and T. 
and $\mathrm{T}$ in groundwater start to decrease from the high steady values of the previous stage.

5. Stage 5. This is another period when fast recharge controls the system discharge. At the beginning, the snowmelt infiltrates through the most conductive karst features. As the contribution of the fast recharge increases in the total system, $\mathrm{EC}$ and $\mathrm{T}$ decrease, as expected. However, once the snowpack covering the study zone disappears, fast recharge ceases. Despite this, the in-transit recharge still feeds the system and therefore $\mathrm{EC}$ and $\mathrm{T}$ in groundwater show an increasing trend.

The relationship between the climatic seasonal variations and the different types of recharge is summarized in Figure 14.

\begin{tabular}{|c|c|c|c|c|c|c|c|c|c|c|c|}
\hline \multicolumn{3}{|c|}{ Stage 1} & \multicolumn{2}{|c|}{ Stage 2} & Stas & & \multicolumn{2}{|c|}{ Stage 4} & \multicolumn{2}{|c|}{ Stage 5} & St. 1 \\
\hline Aug & Sep & Oct & Nov & Dec & Jan & Feb & Mar & Apr & May & Jur & Jul \\
\hline
\end{tabular}
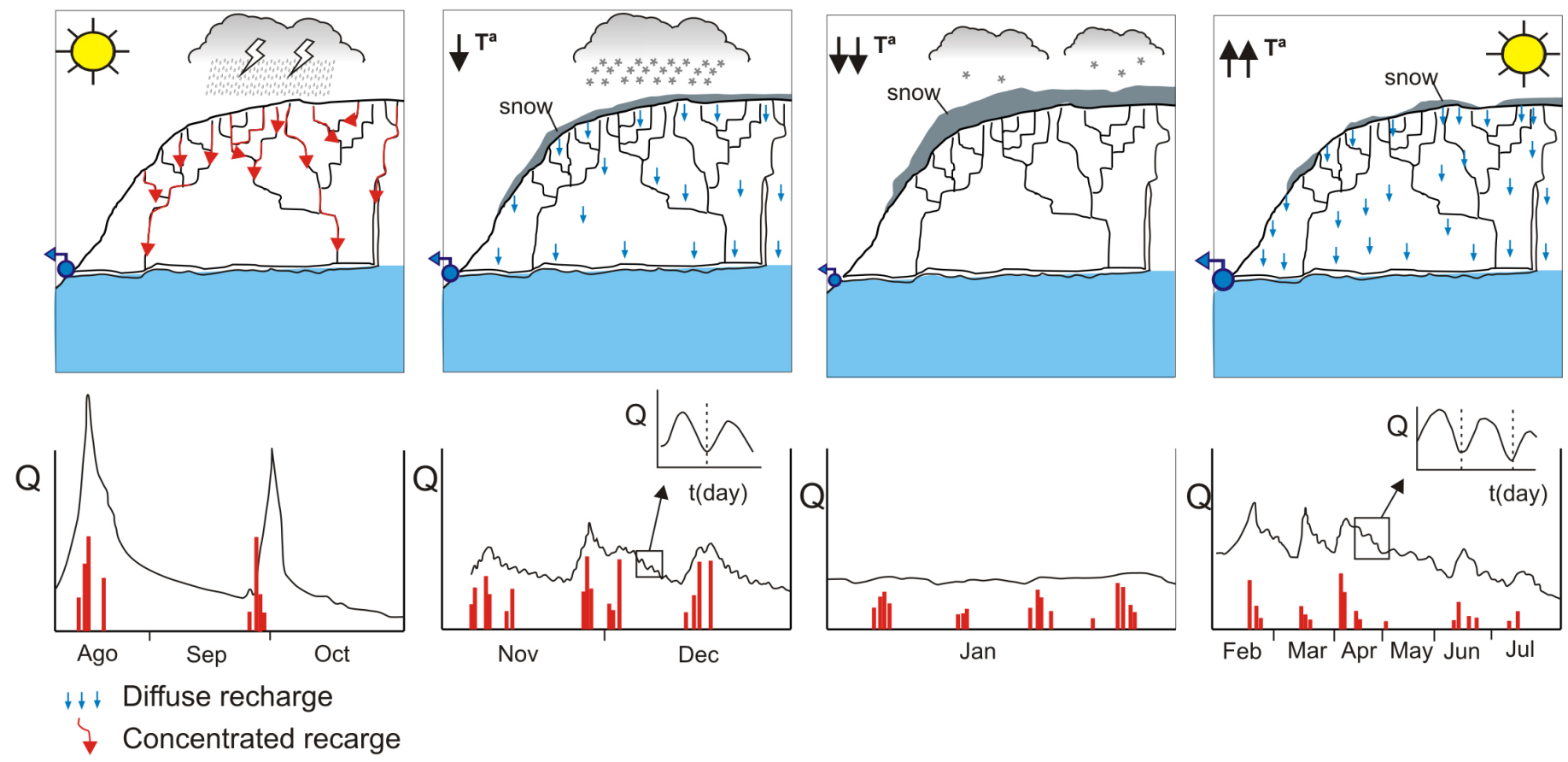

Fig. 14. Schematic conceptual model of recharge observed during the 2018-2019 year in the Garcés karstic system.

\section{Tracer tests}

The tracer tests for this study were conducted in the summer (August 5, 2019) to ensure the system was at the lowest discharge regime, which was indeed attained in the system by mid July 2019, well before starting the tracer tests, as shown in the Garcés system water level evolution (Fig. 13). The four tracers were injected simultaneously. All of them were detected at the control point of the Garcés system located in sump-1 (Fig. 7). The naphtionate and amino-G tracers were injected into the S-60 (3 km away) and the Tartracina $(2.8 \mathrm{~km})$ shafts, respectively, and arrived with similar concentrations and almost simultaneously 4.8 days after the injection (Fig. 15A). The uranine and eosine tracers were injected in the Marbore $(4 \mathrm{~km})$ and the Cigalois $(3.2 \mathrm{~km})$ shafts, respectively. They arrived somewhat later and almost simultaneously, at 9.1 and 9.3 days, respectively. The average tracer circulation velocity was $583 \mathrm{~m} /$ day, $625 \mathrm{~m} /$ day, $439 \mathrm{~m} /$ day, and $344 \mathrm{~m} /$ day for amino-G, naphtionate, uranine, and eosine, respectively. All the observed breakthrough curves present a symetrical pattern with a steep rising limb and a short tail, indicating that tracer transport is controlled by advection in the main conduits. The tracers were not detected in the Font Blanca Spring during these days (Fig. 15B).
Thirteen days after injection of the tracers, a rainfall event occurred in the study zone and a new tracer breakthrough was detected in sump-1 in the Garcés Cave for uranine, eosine and amino-G but not for naphtionate (Fig. 15C). Surprisingly, a synchronous tracer breakthough was detected for uranine and amino-G in the Font Blanca Spring but not for eosine (Fig. 15B), contrary to what happened in sump1. This result might actually show a false negative tracer arrival in the Font Blanca Spring. The lower fluorimeter sensitivity to eosine compared with the other injected tracers should be taken into account. Additionally, only a mass of $0.5 \mathrm{~kg}$ of eosine was injected. Therefore, the tracer could have reached the Font Blanca Spring with a concentration below the fluorometer detection limit.

From the results of the tracer tests, it can be inferred that, in general, the injected tracers migrate towards the $\mathrm{S}$, in a direction which is perpendicular to that defined by the geological structures, until reaching the main conduit of the Garcés Cave. Nevertheless, the tracers can also migrate towards the $\mathrm{SE}$, a direction which is parallel to the overthrust axis. This is supported by the tracer arrival to the Font Blanca Spring. It can be hypothesised that all the tracers reached the Faja Luenga syncline (Fig. 6), which is 

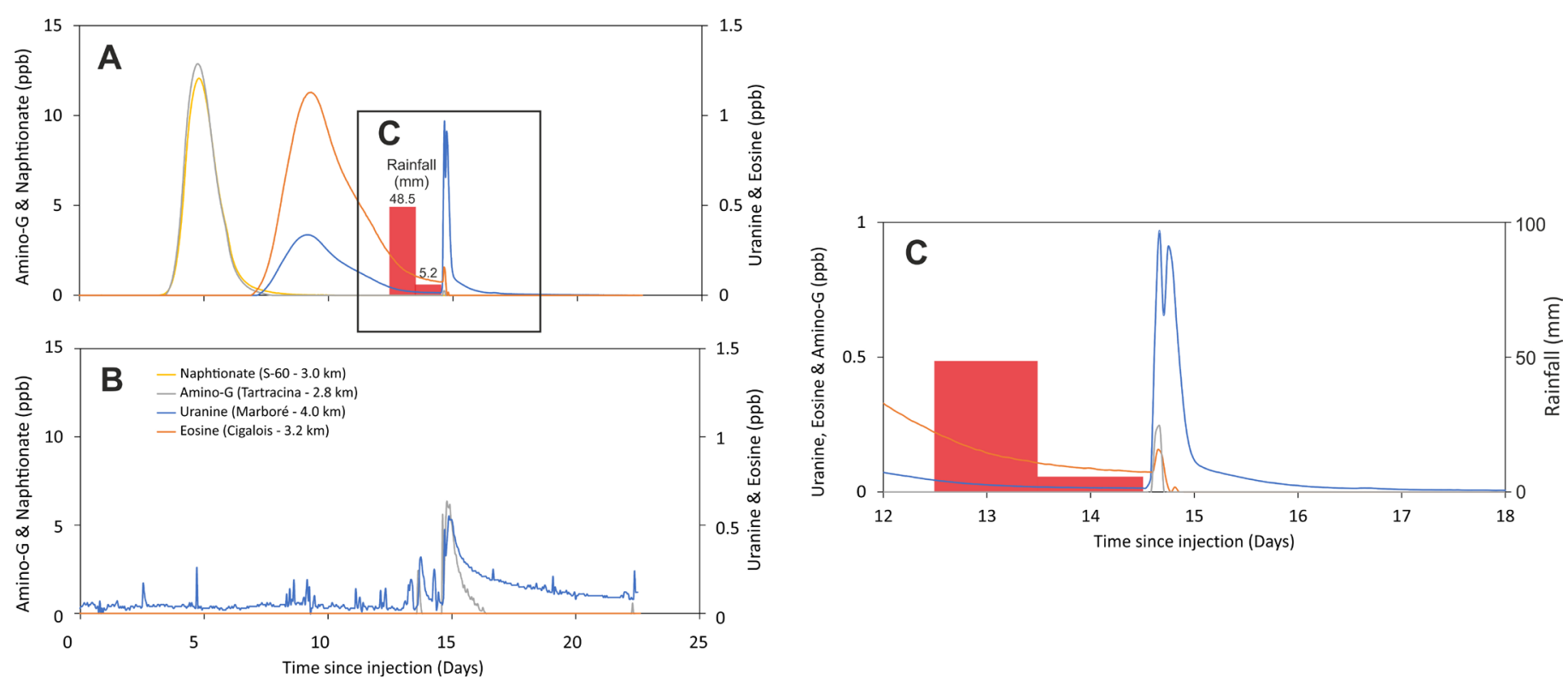

Fig. 15. Tracer breakthrough curves in Garcés sump-1 (A) and Font Blanca Spring (B); C) Detail of the second arrival of tracers to sump-1 in the Garcés Cave, triggered by rainfall.

normally drained by the Garcés system. Nevertheless, the syncline may divert a part of groundwater flow towards the Font Blanca Spring, depending on the hydrological situation in the syncline structure.

To explain the second tracer arrival to sump- 1 in the Garcés Cave, a tracer storage structure is required in the karst system. This role might be played by one of the sumps existing in the ephiphreatic zone of the Faja Luenga syncline (Figs. 16 and 17). The tracers left the temporal storage in the sump after being pushed by a sudden groundwater inflow triggered by the rainfall events registered in the meteorological station of Góriz 13 days after the injection of the tracers. This is congruent with the $\mathrm{T}$ and $\mathrm{EC}$ variations observed during these days in the Garcés system, which correspond to those generated by the summer and autumn storms (Fig. 13).

\section{Hydrogeological functioning of the karst system}

The presence of low permeability sandstone of the Marboré Formation below the soluble PaleoceneEocene materials, and also of stacked thrust folds separated by both reverse and overthrust faults (Fig. 16), determine the cave formation and hence the hydrogeological functioning of the system.

The infiltrated water in the system accumulates in the synclines, which are drained downgradient and flow gently through the epiphreatic zone, enlarging the conduits with a water table cave pattern. Groundwater flow takes place in line through the different syncline structures downgradient. A given syncline receives drainage from the immediately one at higher elevation and drains immediately to the downflow one, and so on until Faja Luenga syncline, where the groundwater flow seems to divide. One part flows normally towards the Garcés syncline before reaching the Garcés Cave (Fig. 16B) and another part moves along the axis of the Faja Luenga syncline towards the Font Blanca Spring, where the main discharge point of the possible perched saturated zone associated to the Faja Luenga syncline is assumed to be (Fig. 17).

\section{DISCUSSION}

The organization of the cave passages in the Marboré, La Roya-Cigalois and Fraile-Tartracina karst systems tends to be repeated, in agreement with the geological structures, which also repeat vertically (Fig. 16). The inlets to the karst systems are located at different altitudes, generally in the formations of the Gallinero Group, with the exception of the Marbore Shaft and Font Blanca Cave, whose entrances are located in the Salarons Formation, close to the contact with the Marboré sandstone. The conduits continue at depth through a succession of shafts and branched galleries with vadose branchwork patterns (Jouves et al., 2017), until culminating in wide, rectilinear and subhorizontal collectors through which the underground rivers circulate. Moreover, dammed areas are also present. These collectors usually end in sumps. The morphology of these collectors is characterized by a water table cave pattern (Audra \& Palmer, 2011, 2015; Jouves, 2017). The projection of the caves in the cross-section of Figure 16B fits with the development of these collectors in the epiphreatic zones of the groundwater storage areas located at different levels. These structures suggest that these collectors serve as conduits that favor groundwater discharge between the successive groundwater storage levels.

The Garcés karst system is developed at the lowest level of the Gallinero Group. It is formed by a single main conduit that collects the drained groundwater from the different water storage structures located above this system (Fig. 16). However, the conduit also receives the local discharge from several small conduits developed in the Garcés syncline, with a $\mathrm{N}$ direction (Fig. 7). After this intersection, the principal conduit tends to follow a direction perpendicular to the axis of the folded structures. Nevertheless, some metres ahead the conduit finaly adapts to the folding axis direction. Sump-1 corresponds to the last point of the Garcés karst system before the Garcés Spring, which is the main discharge point of the system. 


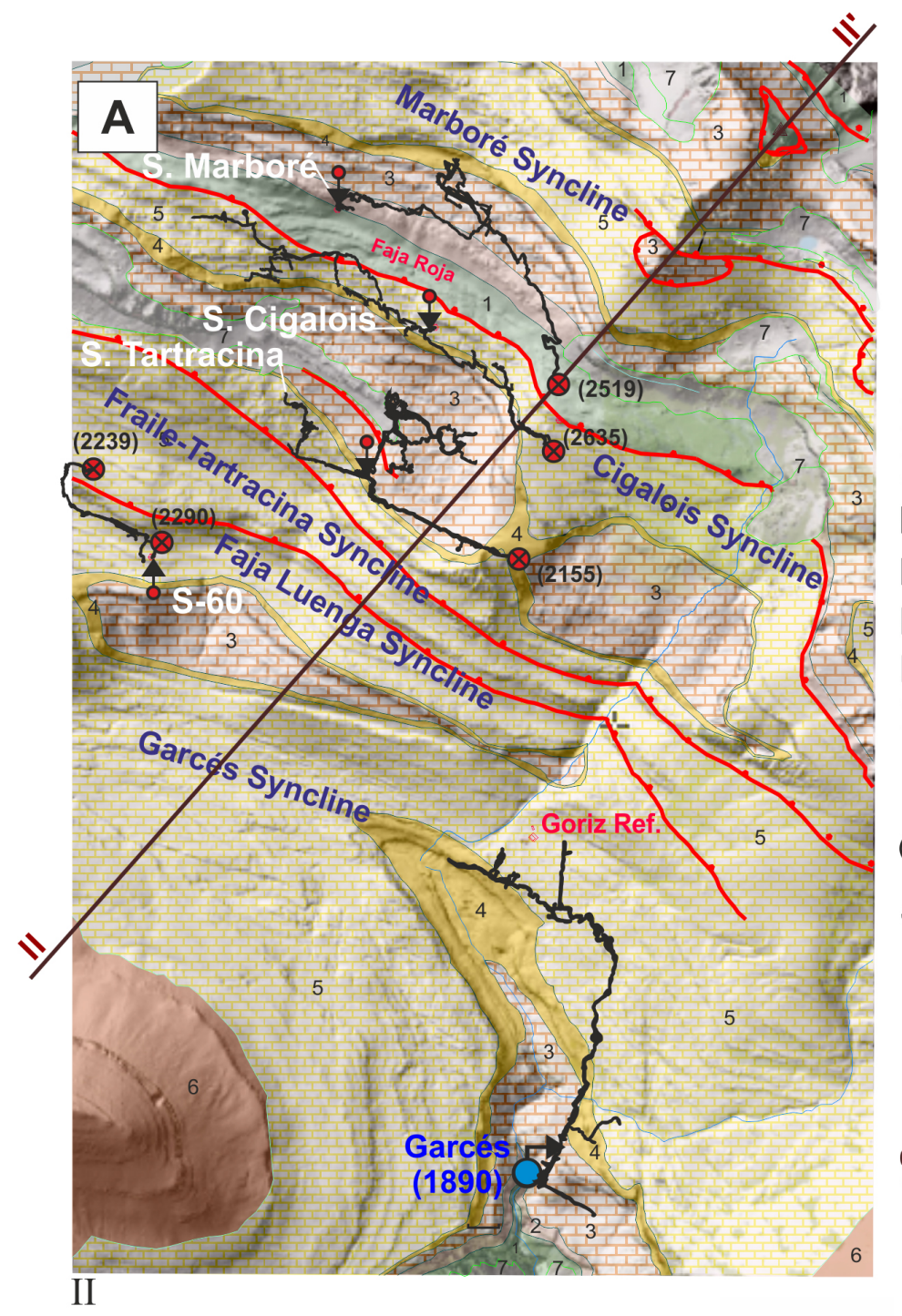

\section{Legend}

1. Sandstone of Marboré. Upper Cretaceous

2. Dolomite and margodolomite. Paleocene

3. Bioclastic limestone Paleocene-Eocene

4. Marl and cuarcitic sandstone.

5 Eilex and bioclastic limestone. Eocene

6 Sandstone. Eocene

7 Quaternary sediments Spring 9 Inyection Point
Altitude (2239) Q Terminal sump and altitude Surveyed karst network

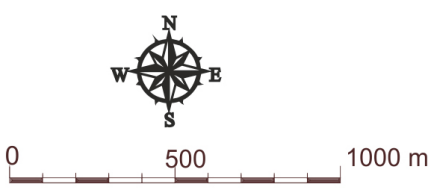

II

\section{B}

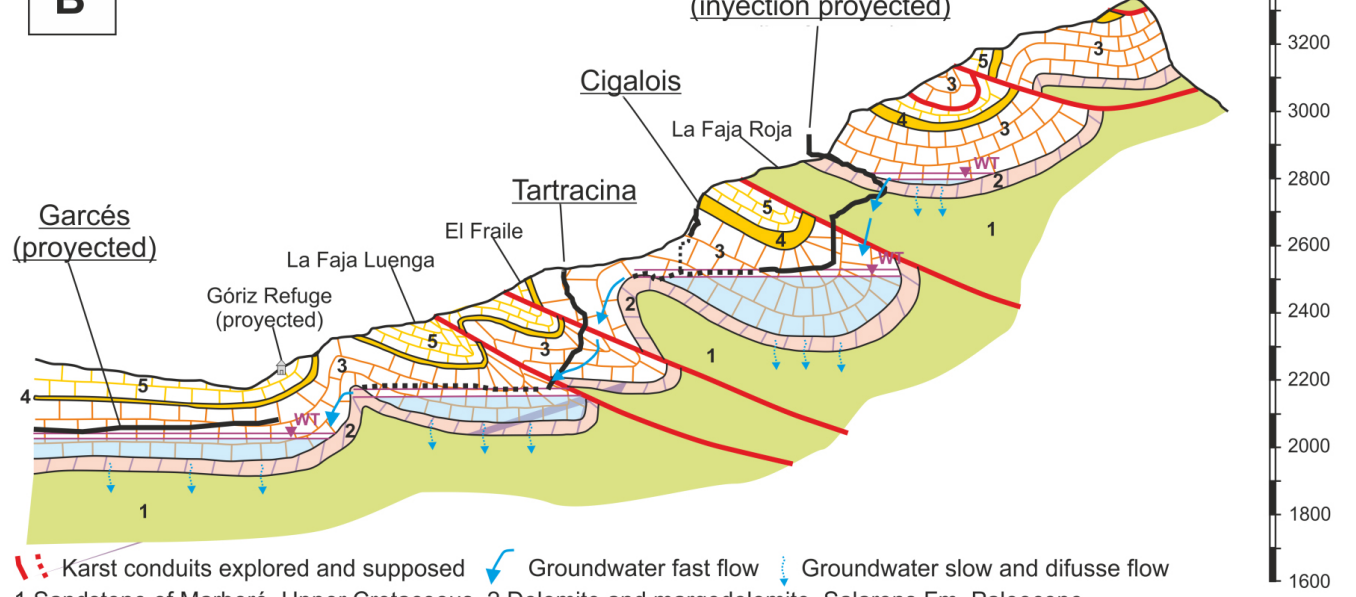

1 Sandstone of Marboré Upper Cretaceous. 2 Dolomite and margodolomite. Salarons Fm. Paleocene.

3 Bioclastic limestone. Gallinera and Sn. Urbez Fm. Paleocene-Eocene. 4 Marl and cuarcitic sandstone. Pardina Fm. Eocene. 5 Bioclastic and chert limestone. Góriz Fm. Eocene.

Fig. 16. A) Hydrogeological map of the study area. The main mapped cavities and their altitudes are included, as well as the tracers' injection points and the main sumps; B) Cross-section with the interpretation of groundwater flow in the system of caves and groundwater storage zones in the synclines. The emplacement of the crosssection is in $(A)$.

The trace of the Font Blanca Cave runs near the contact between the Salarons Formation and the Marboré sandstone, whilst following the direction of the syncline axis of Faja Luenga (Fig. 17). The cave is often flooded and, as with the Garcés Cave, the recently explored conduit presents a water table cave pattern (Figs. 5e and 8).
The repetitive organization of the karst conduit patterns as a set that includes a vadose branchwork and a water table cave, in principle does not agree with the paradigm defined for this type of highly permeable and karstified aquifers, both in exokarstic and endokarstic zones and with a soil devoid of vegetation. The soil partial $\mathrm{CO}_{2}$ pressure was not measured and 


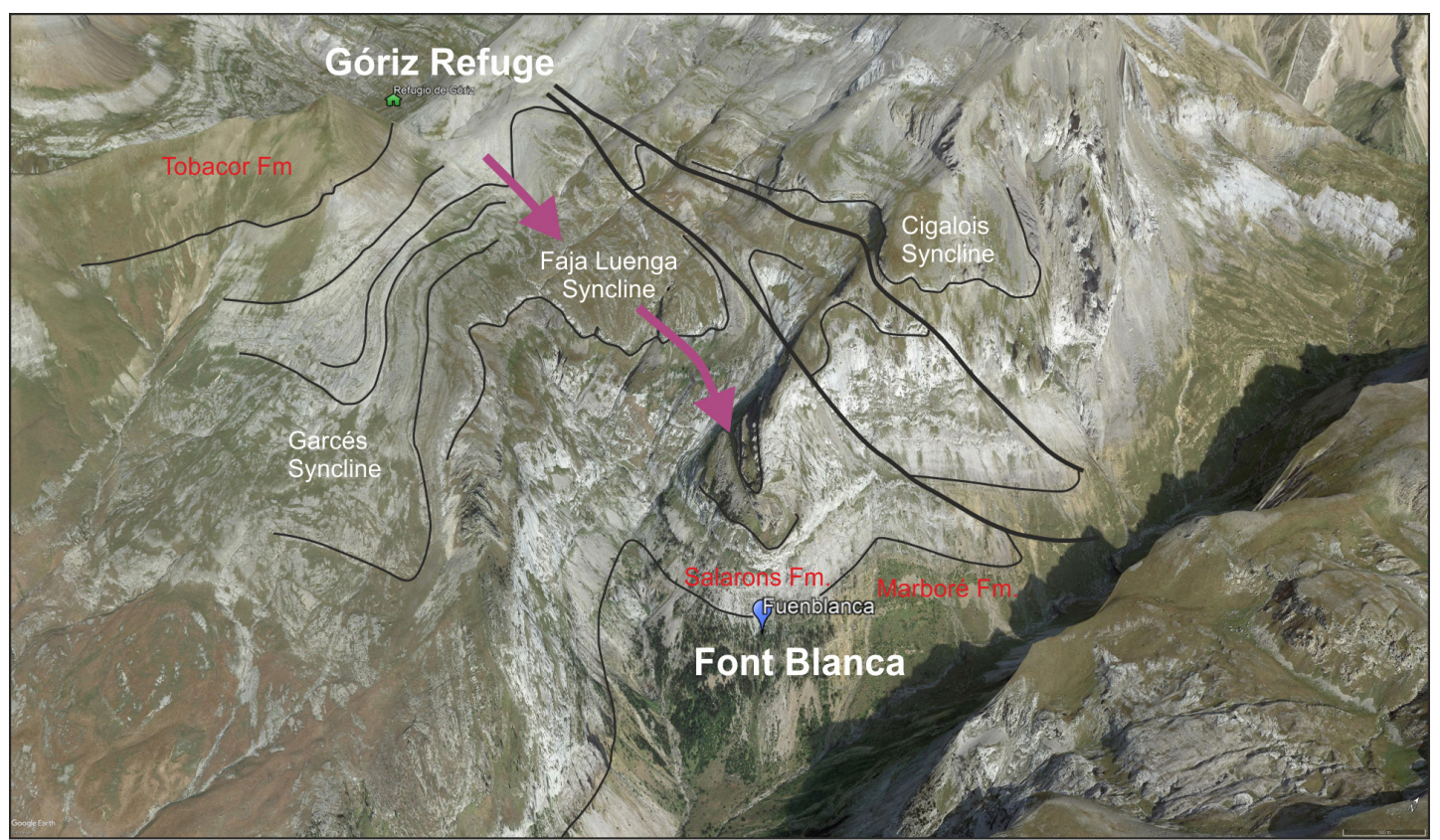

\section{Possible lines of groundwater circulation}

Fig. 17. 3D geological interpretation of the discharge area of the Font Blanca Spring. Three of the main synclines that condition the perched groundwater storage areas are observed. It is assumed that the Font Blanca Spring could be the main discharge point of the Faja Luenga syncline. View of the image from SE to NW, taken from Google Earth (08/09/2017).

results from chemical calculation have to be taken with caution. In any case, this $\mathrm{P}_{\mathrm{CO}_{2}}$ is the atmospheric value or slightly higher due to some biological activity. This produces slightly acidic percolating water, which dissolves the carbonates slowly. Under these conditions, a fast high-flow percolation of meteoric water could be assumed to recharge the aquifer while generating sudden groundwater level variations. In response, this system generated collectors of a looping cave pattern type (Audra \& Palmer, 2011, 2015; Gabrovšek et al., 2014; Jouves, 2017; Häuselmann, 2019) (Fig. 1). However, there is an important factor that prevents fast recharge events during a long period of the year: the high altitude at which the caves are located, which implies a long-lasting snow cover. Nevertheless, other geological factors, such as the connected pores structure (i.e., joints, fractures and limestone primary porosity) of the epiphreatic zone, or even the stratification along the main axis of the general folding structure, are not discarded as additional factors laminating the "in transit recharge" flow and therefore, dampening the recharge peak arrival into the saturated zone.

From November to June, precipitation occurs mainly as snow, which accumulates on the ground, generating snowpacks of significant thickness throughout the snow accumulation season. The presence of the snowpacks hinders fast infiltration events in the system until the end of thaw in early summer. Therefore, during the cold season, recharge diffusion (Figs. 13 and 14) is driven by the infiltration of the snowmelt through the surficial water-conducting features of the area, including swallow holes, but mainly joints and fractures. The snowmelt flows are typically small but increase water infiltration, and therefore aquifer recharge. In fact, this is the most important recharge mechanism for the aquifer in terms of annual recharge volumes (Jódar et al., 2020). During this period, the phreatic level does not experience large variations and groundwater flow is diffuse. As the snowmelt season advances, the epiphreatic zone increases its water content, even up to saturation, thus acting as a perched aquifer that feeds both the highly conductive karst network (shafts and canyons) and the connected porosity structure of the aquifer (Williams, 2008).

The hydrodynamic behavior of the system can also be read from the autocorrelation and cross-correlation functions of the precipitation and groundwater timeseries. The autocorrelation analysis (Fig. 18) shows a small memory effect of 2 days for precipitation (P), whose autocorrelation function resembles a white noise signal. The autocorrelation of the groundwater level in Garcés sump-1 $\left(\mathrm{H}_{\mathrm{GW}}\right)$ decreases fast and presents an initial first stage with a steep slope for 10 days, which is associated to discharge through the karst conduits. After that time, the slope decreases to the point in which the autocorrelation resembles a kind of uncorrelated signal 50 days later. Actually, the fast decrease is in part due to drainage of the conduit system and partly to the early recession of the matrix storage before the logarithmic evolution, although the first one dominates. This has not been studied in detail. The two slopes in the autocorrelation function of $\mathrm{H}_{\mathrm{GW}}$ reveal that the aquifer is a binary karst system, with a total memory effect of 1.5 months for groundwater discharge, which is enough to give to the system some storage that allows water resources regulation capacity.

The fast reaction of the karst conduit driven discharge can be observed in the cross-correlation function between $\mathrm{P}$ and $\mathrm{H}_{\mathrm{GW}}$ (Fig. 18), where the 
reaction of the groundwater level in the Garcés sump1 to precipitation becomes statistically negligible after 2 days. Additionally, the shape of the $\mathrm{P}-\mathrm{H}_{\mathrm{GW}}$ crosscorrelation function shows some symmetry with respect to the lag origin, pointing out the existence of other mechanisms behind the scenes, such as snowmelt, which drive $\mathrm{H}_{\mathrm{GW}}$.

The water collected by the conduits reaches the saturated zone in a short enough time to allow observing the groundwater level variations in the monitoring points, due to the recharge generated by the daily cycles of snowmelt in the morning and refreezing in the afternoon (Fig. 13). The recharged water has a temperature close to the freezing point $\left(\sim 3^{\circ} \mathrm{C}\right)$ and a very low salinity $(\mathrm{EC} \sim 20 \mu \mathrm{S} / \mathrm{cm})$ (Lambán et al., 2015), in agreement with the source of recharge, which is essentially snowmelt. Recharge water is assumed to have a dissolved $\mathrm{CO}_{2}$ content that is almost in equilibrium or slightly higher that of the atmosphere. All these characteristics make the low-rate fast infiltration aggressive to the limestone through which it flows. The constant and low rate water infiltration in the system might be the reason why the collectors observed in the study zone correspond to a water table cave pattern type. The sub-horizontal structure in the core of the synclines where the collector was formed is another possible reason. This pattern is normally associated to karst aquifers in which diffuse recharge is the main recharge process. This usually happens in karst aquifers with a relatively thick soil layer that sustains a steady percolation rate (Tooth \& Fairchild, 2003; Charlier et al., 2012). This is favored by the large water storage capacity of such thick soil horizons (Perrin et al., 2003) or a permeable cover in covered karst (e.g., Crossroad Cave, Palmer, 1991; Buchan caves, Webb et al., 1992). Therefore, an analogy can be defined between the presence of a thick soil layer and the presence of a long-lasting snowpack on the epikarst (Fig. 1), to explain the internal cave pattern developed in high mountain aquifers. Setting aside the obvious differences (e.g., the soil layer limits the infiltration rate), the snowpack dynamics (accretion, snowmelt, refreezing), which is driven by the alpine climate conditions, does exert a control on the infiltration under snow cover (Fayad et al., 2017; Meeks et al., 2017) and thus aquifer recharge during several months.

It is known that the formation of water table or looping caves is largely influenced by floodwater events of epiphreatic origin and recharge variations in the karst (Audra, 1994; Häuselmann et al., 2003). The epiphreatic flood generation is largely conditioned by the internal structure and the hydrological features developed in the epiphreatic zone (Gabrovšek et al., 2018). The recharge variations depend on the infiltration rate of the meteoric water. In high mountain zones, the proportion of snowmelt and rainfall integrating the aquifer recharge highly depends on the elevation of the recharge zone (Lucianetti et al., 2020). In the recharge zone of the Garcés karst system, the snowmelt flows diffusely through the snowpack, minimizing surface runoff. The slow snowmelt rate favors water infiltration through the network of joints and fractures, thus maximizing

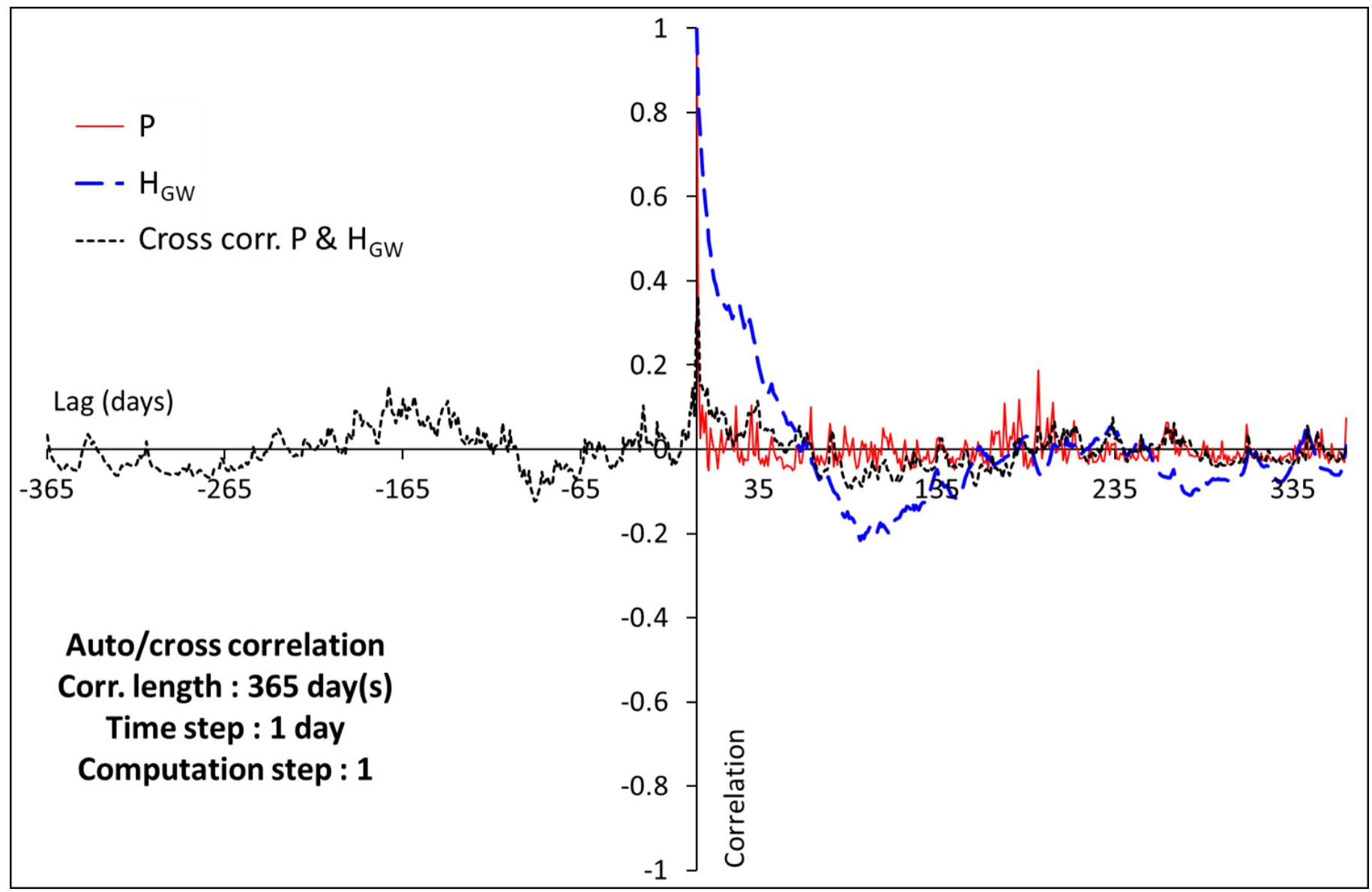

Fig. 18. Correlograms for precipitation ( $P$, red line), and groundwater level in Garcés sump-1 ( $H_{G w}$, blue dashed line), and cross-correlogram for $P$ and $\mathrm{H}_{\mathrm{GW}}$ (black dotted line). 
aquifer recharge spatially while maintaining moderate drainage rates over time. Therefore, the joint effect of the snowmelt dynamics and the epiphreatic structure, which is controlled by the connected porosity and small joints and fractures (Jódar et al., 2020), prevent the generation of the sudden and rapid recharge pulsations in the system, which are closely related with the looping cave structure generation.

The proposed analogy between the behavior of the soil horizon and the snowpack regarding their capacity of laminating the infiltration of precipitation, provides a consistent morphological model of the expected cave patterns for high mountain karst aquifers. This is extremely relevant for building and supporting the conceptual model definition of such aquifer systems, which are often poorly characterized. This might be the case of the Cotiella Massif (2,912 m a.s.1.), which is located only $25 \mathrm{~km}$ to $\mathrm{SE}$ of the PNOMP. In this karst massif, Belmonte and Sancho (2012) report the existence of both a water-table cave (Espluga Alta de Lasgüériz), and a looping-cave (Pot au Feu). The water-table cave is in the upper zone of the massif. The hydrological recharge basin associated to this cave is bounded by the highest peaks of the massif, where alpine climate conditions prevail throughout the year. The looping-cave is in the lower part of the massif where the climate conditions are not so severe, and precipitation usually occurs as rainfall. In this case, the role of snowmelt dynamics in recharge seems to condition the speleogenesis of the upper water-table cave, whereas the lack of such snowmelt dynamics appears to condition the looping structure of the lower cave. Further research is needed to shed light on the role played by the snowmelt recharge in high mountain karst speleogenesis.

\section{CONCLUSIONS}

The recharge of karst aquifers located in high mountain zones may be controlled by the presence and dynamics of the snowpack during the accretion and snowmelt seasons. The water recharging the aquifer during the snowmelt season is sligthy aggressive to the limestone due to the $\mathrm{CO}_{2}$ content.

Snowmelt produces a steady low-rate infiltration and fast recharge until the snowpack completely melts. The low recharge rates follow large groundwater level variations, thus favoring the generation of conduits with a water table cave pattern type. The generation of these patterns have also been strongly influenced by the geological structure, with staggered subhorizontal levels related to the axis of the synclines, where these conduits are developed.

In the PNOMP, the karstic conduits are stacked with a repetitive pattern, reflecting the complex geological structure of the vertically stacked overthrust sheets. A conduit set connects two consecutive subhorizontal perched storage zones generated in the inner part of the corresponding syncline structures. The conduit pattern set includes conduits of the branchwork pattern type in the vadose zone and a main water table cave pattern conduit in the epiphreatic zone. The tracer tests confirmed the hydrogeological connection between all of these temporal perched storage zones, with a short transtit time, even during the hydrologic low-flow period.

The lack of geomorphological description of karst aquifers located in alpine zones reveals the difficulties inherent to these activities, imposed by the harsh working conditions in the high mountain zones. Further research is needed in this regard to confirm the role played by the snowmelt recharge in the generation of water table cave pattern conduits as the main draining structure of karst systems located in high mountain zones.

\section{ACKNOWLEDGMENTS}

This research was undertaken in the framework of the PIRAGUA project. The project EFA210/16 PIRAGUA is co-founded by the European Regional Development Fund (ERDF) through the Interreg $\mathrm{V}$ Spain-France-Andorre Programme (POCTEFA 20142020) of the European Union. The authors would like to thank the Ordesa and Monte Perdido National Park Direction (Gobierno de Aragón), especially Elena Villagrasa from DGA, Fernando Carmena and Ignacio Gómez from SARGA, the Góriz Mountain Hut Wardens, Marta Quintana, and Sanda Iepure. We are very grateful to G.E. OTXOLA E.T. Speleological Group (Grupo espeleología Otxola Espeleologi taldea) for their help in injecting the fluorescent dye tracers during the tracer test campaigns., We also acknowledge both the OTXOLA and SCC (Spéléo Club du Comminges) for providing detailed information of the different karst systems draining the study zone. Meteorological data have been provided by the Spanish Meteorological Agency (AEMET).

We would also like to thank Drs. Jo De Waele, Philipp Häuselmann, Stéphane Jaillet, and one anonymous reviewer for their constructive comments and suggestions, which led to a substantial improvement of the paper.

Authorship statement: LJL and JJ designed and directed the study. LJL, JJ, AGR and SMR performed the measurements. JMS performed the geological cartography. AGR, JJ, SMR, JH, LJL, AZ, IA, EC analyzed the data. AGR and JJ wrote most of the paper with input from all authors. JMS wrote the geological setting with input from all authors.

\section{REFERENCES}

Audra, P., Bini, A., Gabrovšek, F., Häuselmann, P., Hobléa, F., Jeannin, P.Y., Kunaver, J., Monbaron, M., Šušteršič, F., Tognini, P., Trimmel, H., Trimmel, H., Wildberger, A., 2007. Cave and karst evolution in the Alps and their relation to paleoclimate and paleotopography. Acta Carsologica, 36(1), 53-67. https://doi.org/10.3986/ac.v36i1.208

Audra, P., Palmer, A.N., 2011. The pattern of caves: controls of epigenic speleogenesis. Géomorphologie: Relief, Processus, Environnement, 17(4), 359-378. https://doi.org/10.4000/geomorphologie.9571

Audra, P., Palmer, A.N., 2013. The vertical dimension of karst: controls of vertical cave pattern. In: Shroder, 
J.E. (Ed.), Treatise on geomorphology. Volume 6 , Karst Geomorphology. Academic Press, p. 186-206. https:/doi.org/10.1016/B978-0-12-374739-6.00098-1

Audra, P., Palmer, A.N., 2015. Research frontiers in speleogenesis. Dominant processes, hydrogeological conditions and resulting cave patterns. Acta Carsologica, 44(3), 315-348.

https://doi.org/10.3986/ac.v44i3.1960

Audra, P., 1994. Karsts alpins - Genèse de grands réseaux souterrains. Karstologia Mém oires, 5(5), 217-247.

Belmonte, A., Sancho, C., 2012. Endokarst y glaciarismo en el valle del Irués (Macizo de Cotiella, Pirineo Oscense): evolución paleoambiental durante el Cuaternario. Lucas Mallada, 14, 9-29.

Benito Alonso, J.L., 2006. Vegetación del Parque Nacional de Ordesa y Monte Perdido. Serie Investigación 50. Consejo de Protección de la Naturaleza de Aragón. Zaragoza.

Calvet, M., Hez, G., Gunnell, Y., Jaillet, S., 2019. Le karst du synclinal de Villefranche, enregistreur de l'incision de la vallée de la Têt. Boletín de la Sociedad Española de Espeleología y Ciencias del Karst, 14, 15-32.

Charlier, J.B., Bertrand, C., Mudry, J., 2012. Conceptual hydrogeological model of flow and transport of dissolved organic carbon in a small Jura karst system. Journal of Hydrology, 460, 52-64.

https://doi.org/10.1016/j.jhydrol.2012.06.043

Choukrune, P., 1989. The ECORS deep seismic profile reflection data and the over-rall estructure of an orogenic belt. Tectonics, 8(1), 23-39. https://doi.org/10.1029/TC008i001p00023

Columbu, A., Sauro, F., Lundberg, J., Drysdale, R., De Waele, J., 2018. Palaeoenvironmental changes recorded by speleothems of the southern Alps (Piani Eterni, Belluno, Italy) during four interglacial to glacial climate transitions. Quaternary Science Reviews, 197, 319-335.

https://doi.org/10.1016/j.quascirev.2018.08.006

ENSG, 1990. Compte Rendu du tracage de l'avenc du Marboré (Huesca, Espagne).

Fayad, A., Gascoin, S., Faour, G., López-Moreno, J. I., Drapeau, L., Le Page, M., Escadafal, R., 2017. Snow hydrology in Mediterranean mountain regions: A review. Journal of Hydrology, 551, 374-396. https://doi.org/10.1016/j.jhydrol.2017.05.063

Federation Française de Speleology (FFS), 1988. U. V. Technique. Stage instructeur Marbore 88.

Ford, D.C., Williams, P.W., 2007. Karst hydrogeology and geomorphology ( $2^{\text {nd }}$ Ed.). John Wiley \& Sons, 562 p. https://doi.org/10.1002/9781118684986

Frisia, S., Bini, A., Quinif, Y., 1993. Morphologic, crystallographic and isotopic study of an ancient flowstone (Grotta di Cunturines, Dolomites)Implications for paleoenvironmental reconstructions. Speleochronos, 5, 3-18.

Grup d'Espeleologia de Badalona, 1963. Cavernas, 1.

Grup d'Espeleologia de Otxola E.T., 2015, 2016, 2017, 2018, 2019. Memorias de Garcés.

http://otxola.blogspot.com.es/p/trabajos.html (accessed 3 April 2020).

Gabrovšek, F., Häuselmann, P., Audra, P., 2014. 'Looping caves' versus 'water table caves': The role of base-level changes and recharge variations in cave development. Geomorphology, 204, 683-691. https://doi.org/10.1016/j.geomorph.2013.09.016

Gabrovšek, F., Peric, B., 2006. Monitoring the flood pulses in the epiphreatic zone of karst aquifers: The case of Reka river system, Karst plateau, SW Slovenia. Acta Carsologica, 35(1), 35-45.

https://doi.org/10.3986/ac.v35i1.241
Gabrovšek, F., Peric, B., Kaufmann, G., 2018. Hydraulics of epiphreatic flow of a karst aquifer. Journal of Hydrology, 560, 56-74. https://doi.org/10.1016/j.jhydrol.2018.03.019

Haenel, R., Rybach, L., Stegena, L., 1988. Handbook of terrestrial heat-flow density determination. Solid Earth Science Library, Kluwer Academic Publishers, 486 p.

Harmand, D., Adamson, K., Rixhon, G., Jaillet, S., Losson, B., Devos, A., Hez, G. Calvet, M., Audra, P., 2017. Relationships between fluvial evolution and karstification related to climatic, tectonic and eustatic forcing in temperate regions. Quaternary Science Reviews, 166, 38-56.

https://doi.org/10.1016/j.quascirev.2017.02.016

Häuselmann, P., 2002. Cave genesis and its relationship to surface processes: Investigations in the Siebenhengste region (BE, Switzerland). PhD Thesis, Université de Fribourg, $168 \mathrm{p}$.

Häuselmann, P., 2019. Solution caves in regions of highrelief. In: White, W.B., Culver, D.C., Pipan, T. (Eds.), Encyclopedia of caves ( $3^{\text {rd }}$ Ed.). Academic Press, New York, p. 943-954.

https://doi.org/10.1016/B978-0-12-814124-3.00111-4

Häuselmann, P., Plan, L., Pointner, P., Fiebig, M., 2020. Cosmogenic nuclide dating of cave sediments in the Eastern Alps and implications for erosion rates. International Journal of Speleology, 49(2), 107-118. https://doi.org/10.5038/1827-806X.49.2.2303

Häuselmann, Ph., Jeannin, P.-Y., Monbaron, M., 2003. Role of epiphreatic flow and soutirages in conduit morphogenesis: the Bärenschacht example (BE, Switzerland). Zeitschrift Geomorphologie, 47(2), 171-190.

Holzkamper, S., Spötl, C., Mangini, A., 2005. Highprecision constraints on timing of Alpine warm periods during the middle to late Pleistocene using speleothem growth periods. Earth Planet Science Letters, 236, 751764. https://doi.org/10.1016/j.eps1.2005.06.002

Jennings, J.N., 1985. Karst geomorphology. Blackwell, Oxford, $293 \mathrm{p}$.

Jódar, J., Custodio, E., Lambán, L. J., Martos-Rosillo, S., Herrera-Lameli, C., Sapriza-Azuri, G., 2016. Vertical variation in the amplitude of the seasonal isotopic content of rainfall as a tool to jointly estimate the groundwater recharge zone and transit times in the Ordesa and Monte Perdido National Park aquifer system, north-eastern Spain. Science of the Total Environment, 573, 505-517. https://doi.org/10.1016/j.scitotenv.2016.08.117

Jódar, J., González-Ramón, A., Martos-Rosillo, S., Heredia, J., Herrera, C., Urrutia, J., Caballero, Y., Zabaleta, A., Antigüedad, I., Custodio, E., Lambán, L.J., 2020. Snowmelt as a determinant factor in the hydrogeological behaviour of high mountain karst aquifers: The Garcés karst system, Central Pyrenees (Spain). Science of the Total Environment, 748, 141363. https://doi.org/10.1016/j.scitotenv.2020.141363

Jouves, J., Viseur, S., Arfib, B., Baudement, C., Camus, H., Collon, P., Guglielmi, Y., 2017. Speleogenesis, geometry, and topology of caves: A quantitative study of 3D karst conduits. Geomorphology, 298, 86-106. https://doi.org/10.1016/j.geomorph.2017.09.019

Klimchouk, A.B., Samokhin, G.V., Kasian, Y.M., 2009. The deepest cave in the world in the Arabika massif (Western Caucasus) and its hydrogeological and paleogeographic significance. Proceedings of the $15^{\text {th }}$ International Congress of Speleology, Kerrville, TX, 898-905.

Lambán L.J., Jódar, J., Custodio, E., 2014. Caracterización hidrogeoquímica e isotópica del agua subterránea en macizos carbonatados de alta montaña: el Parque 
Nacional de Ordesa y Monte Perdido (Pirineo Central, España). Proceedings of the V Congreso Colombiano de Hidrogeología. Medellín, Colombia, 601-608.

Lambán, L.J., Jódar, J., Custodio, E., 2019. Investigaciones hidrogeológicas en el Parque Nacional de Ordesa y Monte Perdido (Huesca, España). Boletín Geológico y Minero, 130(4), 615-640.

https://doi.org/10.21701/bolgeomin.130.4.003

Lambán, L.J., Jódar, J., Custodio, E., Soler, A., Sapriza, G., Soto, R., 2015. Isotopic and hydrogeochemical characterization of high-altitude karst aquifers in complex geological settings. The Ordesa and Monte Perdido National Park (Northern Spain) case study. Science of the Total Environment, 506, 466-479. https://doi.org/10.1016/j.scitotenv.2014.11.030

Lucianetti, G., Penna, D., Mastrorillo, L., Mazza, R., 2020. The role of snowmelt on the spatio-temporal variability of spring recharge in a Dolomitic Mountain Group, Italian Alps. Water, 12(8), 2256.

https://doi.org/10.3390/w12082256

Mangin, A., 1984. Pour une meilleure connaissance des systèmes hydrologiques à partir des analyses corrélatoire et spectrale. Journal of Hydrology, 67 (1/4), 25-43. https://doi.org/10.1016/0022-1694(84)90230-0

Meeks, J., Moeck, C., Brunner, P., Hunkeler, D., 2017. Infiltration under snow cover: Modeling approaches and predictive uncertainty. Journal of Hydrology, 546, 1627. https://doi.org/10.1016/j.jhydrol.2016.12.042

Padilla, A., Pulido, A., 1995. Study of hydrographs of karstic aquifers by means of correlation and crossspectral analysis. Journal of Hydrology, 168(1), 73-89. https://doi.org/10.1016/0022-1694(94)02648-U

Palmer, A.N., 1991. Origin and morphology of limestone caves. Geological Society of America Bulletin, 103(1), 1-21. https://doi.org/10.1130/0016-7606(1991)103< 0001:OAMOLC $>2.3 . \mathrm{CO} ; 2$.

Palmer, A.N. 2007. Cave Geology. Cave books, Dayton, 454 p.

Peel, M.C., Finlayson, B.L., McMahon, T.A., 2007. Updated world map of the Köppen-Geiger climate classification. Hydrology of Earth System Science, 11, 1633-1644.

https://doi.org/10.5194/hess-11-1633-2007

Perrin, J., Jeannin, P.Y., Zwahlen, F., 2003. Epikarst storage in a karst aquifer: a conceptual model based on isotopic data, Milandre test site, Switzerland. Journal of Hydrology, 279(1-4), 106-124. https://doi.org/10.1016/S0022-1694(03)00171-9

Plan, L., Filipponi, M., Behm, M., Seebacher, R., Jeutter, P., 2009. Constraints on alpine speleogenesis from cave morphology - a case study from the eastern Totes Gebirge (Northern Calcareous Alps, Austria). Geomorphology, 106(1-2), 118-129. https://doi.org/10.1016/j.geomorph.2008.09.011

Polo, E., 2015. Uso y manejo de nuevas tecnologias y herramientas SIG a partir de datos hidrogeológicos en el Parque Nacional de Ordesa y Monte Perdido. Unpublished Master's Thesis, Department of Geography and Regional Planning, University of Zaragoza.

Prelovšek, M., 2009. Present-day speleogenetic processes, factors and features in the epiphreatic zone. Doctoral dissertation, Univerza v Novi Gorici, Fakulteta za podiplomski študij, $297 \mathrm{p}$.

Puch, C., 1998. Grandes cuevas y simas de España. Espeleo Club de Gràcia, Badalona, 794 p.

Pujalte, V., Robador, A., Payros, A., Samsó, J.M., 2016. A siliciclastic braid delta within a lower Paleogene carbonate platform (Ordesa- Monte Perdido National
Park, souther Pyrenees, Spain): Record of the Paleocene-Eocene Thermal Maximum perturbation. Paleogeography, Palaeoclimatology, Palaeoecology, 459, 453-470. https://doi.org/10.1016/j.palaeo.2016.07.029

Ríos-Aragüés, L.M., 2003. Introducción al mapa geológico del Parque Nacional de Ordesa y Monte Perdido. Boletín de la Sociedad Española de Espeleología y Ciencias del Karst, 5, 84-99.

Robador, A., Belmonte, A., Carcavilla, L., Samsó, J.M., Martínez-Rius, A., 2018. Mapa Geológico del Parque Nacional de Ordesa y Monte Perdido a escala 1:25.000. Seri GeoNatur, editada por el IGME.

Robador, A., Pujalte, V., Samsó, J.M., Payros, A., 2009. Registro geológico del máximo térmico del Paleoceno Eoceno en el Parque Nacional de Ordesa y Monte Perdido (Pirineo Central). Geogaceta, 46, 111-114.

Robador, A., Samsó, J.M., Pujalte, V., Oliva, B., Gil, I., Soto, R., Payros, A., Rosales, I., Tosquella, J., 2010. Cartografia Geológica a escala 1:25.000 del Parque Nacional de Ordesa y Monte Perdido. In: Ramirez, L., Asensio, B. (Eds.). Proyectos de Investigación en Parques Nacionales 2006-2009. Organismo Autónomo de Parques Nacionales, Madrid, p. 7-28.

Rodríguez-Fernández, L.R., Robador, A., Carcavilla, L., Samsó, J.M., 2013. Guía Geológica de Parque Nacional de Ordesa y Monte Perdido. IGME y Organismo Autónomo de Parques Nacionales, 212 p.

Ruiz Zubikoa, J.J., 2017. La Cueva de Garcés. Karaitza, 25, 60-71

Sachsenhofer, R.F., Bechtel, A., Reischenbacher, D., Weiss, A., 2003. Evolution of lacustrine systems along the Miocene Mur-Mürz fault system (Eastern Alps, Austria) and implications on source rocks in pull-apart basins. Marine and Petroleum Geology, 20(2), 83-110. https://doi.org/10.1016/S0264-8172(03)00018-7

Sartégou, A., Blard, P. H., Braucher, R., Bourlès, D. L., Sorriaux, P., Zimmermann, L., Laffitte, A., Tibari, B., Leanni, L., Guillou, V., Aumaître, G., Keddadouche, K., Bourdet, A., 2020. Late Cenozoic evolution of the Ariège River valley (Pyrenees) constrained by cosmogenic ${ }^{26} \mathrm{Al} /{ }^{10} \mathrm{Be}$ and ${ }^{10} \mathrm{Be} /{ }^{21} \mathrm{Ne}$ dating of cave sediments. Geomorphology, 371, 107441. https://doi.org/10.1016/j.geomorph.2020.107441

Sauro, F., Mecchia, M., Tringham, M., Arbenz, T., Columbu, A., Carbone, C., Pisani, L., De Waele, J., 2020. Speleogenesis of the world's longest cave in hybrid arenites (Krem Puri, Meghalaya, India). Geomorphology, 359, 107160.

https://doi.org/10.1016/j.geomorph.2020.107160

Sauro, F., Piccini, L., Menichetti, M., Artoni, A., Migliorini, E., 2012. Lithological and structural guidance on speleogenesis in Spluga della Preta Cave, Lessini Mountains (Veneto-Italy). Geografia Fisica e Dinamica Quaternaria, 35, 167-176.

https://doi.org/10.4461/GFDQ.2012.35.15

Speleo Club du Comminges, 2010-2012. Compte rendu de recherches spélèologiques-scientifiques (et résultats complémentaires). Las Olas 2010 and 2012.

SCAL, 1963. Bulletin du Spéléo Club Alpin Languedocien. Numéro special Marboré, Montpellier, France.

Séguret, M., 1972. Etude tectonique des nappes de series décollées de la partie centrale du versant sud des Pyrénées. Caractère synsédimentaire, rôle de la compression et de la gravité. Unpublished PhD Thesis, Série Géologie, Montpellier. 155 p.

Thornton, J. M., Mariethoz, G., Brauchli, T. J., Brunner, P., 2019. Efficient multi-objective calibration and uncertainty analysis of distributed snow simulations in rugged alpine terrain. The Cryosphere Discussions, 1-48. https://doi.org/10.5194/tc-2019-181 
Tooth, A.F., Fairchild, I.J., 2003. Soil and karst aquifer hydrological controls on the geochemical evolution of speleothem-forming drip waters, Crag Cave, southwest Ireland. Journal of Hydrology, 273(1-4), 51-68.

https://doi.org/10.1016/S0022-1694(02)00349-9

Van Essen Instruments, 2016. Product Manual Diver (Last access 22/04/2020) https://www.eijkelkamp. com/download.php?file=M21111e_Diver_118b.pdf

Vosteen, H.D., Rath, V., Clauser, C., Lammerer, B., 2006. A review of the thermal regime of the Eastern Alps with respect to the effects of paleoclimate and exhumation. Tectonophysics, 414(1-4), 157-167.

https://doi.org/10.1016/j.tecto.2005.10.022

Wagner, T., Fritz, H., Stüwe, K., Nestroy, O., Rodnight, H., Hellstrom, J., Benischke, R., 2011. Correlations of cave levels, stream terraces and planation surfaces along the River Mur-Timing of landscape evolution along the eastern margin of the Alps. Geomorphology, 134(1-2), 62-78. https://doi.org/10.1016/j.geomorph.2011.04.024

Webb, J.A., Fabel, D., Finlayson, B.L., Ellaway, M., Shu, L., Spiertz, H.P., 1992. Denudation chronology from cave and river terrace levels: the case of the Buchan Karst, southeastern Australia. Geological Magazine, 129(3), 307-317.

https://doi.org/10.1017/S0016756800019245

White, W.B., 1988. Geomorphology and hydrology of karst terrains, Oxford University Press, New York, 464 p.

Williams, P.W., 2008. The role of the epikarst in karst and cave hydrogeology: a review. International Journal of Speleology, 37(1), 1-10.

https://doi.org/10.5038/1827-806X.37.1.1 